\title{
Bacterial Seed Endophytes of the Holoparasitic Cistanche Armena and $C$. Phelypaea (Orobanchaceae) from Saline Habitats: Semi- Deserts vs Flooded Coasts
}

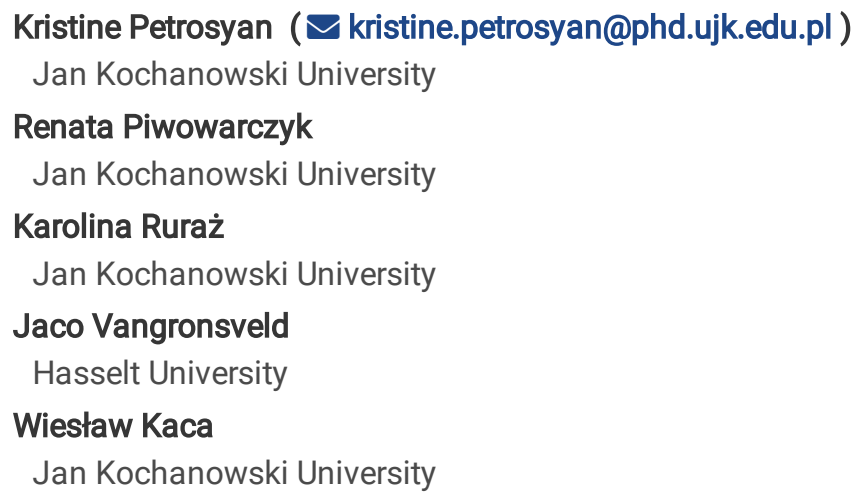

Research Article

Keywords: Cistanche armena and C. phelypaea, Paenibacillus, biochemical traits, endomicrobiome.

Posted Date: November 18th, 2021

DOI: https://doi.org/10.21203/rs.3.rs-1043093/v1

License: @ (1) This work is licensed under a Creative Commons Attribution 4.0 International License. Read Full License 


\section{Abstract}

The current study compares the bacterial seed endomicrobiomes of the endemic holoparasitic plant species Cistanche armena and $C$. phelypaea. Both species thrive in habitats that are saline but with a very different soil water status. The study aims to uncover how environmental conditions influence the diversity of the bacterial communities of seeds of these holoparasites and also highlights the physiological activities, several enzymatic and PGP traits of culturable endophytes that may support the tolerance of their hosts to abiotic stresses. A combination of culture-dependent and molecular techniques was employed for the identification of the seed endomicrobiome (culturable and unculturable). From the seeds of both parasitic plant species closely related strains were isolated. Sixteen phyla, 323 genera and 710 bacterial species were identified, mainly Gram negative, halotolerant bacteria with an environmental origin. Most of the isolates were endospore forming, halotolerant and alkaliphile Bacillus spp. which suggests that the endophytic bacteria of $C$. armena and $C$. phelypaea seeds possess traits that are correlated with the natural habitat of their hosts. The Paenibacillus strains from both plant species demonstrate similar biochemical traits. Although the seed endophytic microbiomes of $C$. armena and $C$. phelypaea contain a high number of common bacterial taxa, also remarkable differences exist. We demonstrated that the diversity of the bacterial communities is related to the environmental conditions, water status or abiotic stresses.

\section{Introduction}

With approximately 4,750 species, parasitic plants constitute $1.6 \%$ of the angiosperms ${ }^{1}$. Parasitism, especially holoparasitism, represents the most extreme interaction between plants, with strong associations between host and parasite biogeography, ecology, and probably with diversification ${ }^{2}$. Orobanchaceae is the largest parasitic plant family with 102 genera and over 2100 species $^{1}$. A particularity of these plants is their production of huge numbers of seeds, which are also among the smallest in seed plants, with a length of less than $1 \mathrm{~mm}$, often called 'dust seeds' ${ }^{3-5}$.

The reticulated testa of these seeds with polygonal and sometimes deeply submerged walls might enhance the contact of the seed surface with water or facilitate the seed dispersal by wind. The endothelium (inner testa layer) containing mucilage and labyrinthine walls, allows rapid absorption of water, which is crucial for imbibition and subsequent germination ${ }^{6}$. The degree of lignification of the secondary walls of epidermal cells of the testa in Orobanchaceae is variable; the cutinized endothelium has a protective role in the underground part of the plant life cycle $\mathrm{e}^{7,8}$. The seeds possess a unique simple structure, contain only a reduced embryo, as a spherical body without a plumule, and radicle or cotyledons. Lipids are the main storage material in the seeds of Orobanchaceae ${ }^{6}$. For germination, Cistanche seeds need to be very nearby their preferred host. Germination depends on hormones-strigolactones exuded from the host root ${ }^{9}$. Seeds of Cistanche seem to be resistant to harsh environmental conditions and stay viable in the soil for several dozens of years ${ }^{10}$.

Recently, different endophytic bacteria were isolated from tissues of holoparasitic plant species (Table 1). The microbiome of the Phelipanche aegyptiaca in different developmental stages was investigated by lasur Kruh et al. ${ }^{11}$. Surface-sterilized tissues of infected and non-infected roots, haustoria and shoots harbored bacteria belonging to the Proteobacteria (Rhizobium, Pseudomonas, Comamonadaceae sp., Sphingomonas and Burkholderia, Actinobactersp., Bacillus sp.). In addition, Novosphingobium and Methylophilus were reported as specific endophytes for this plant species ${ }^{11}$. A study of the endophytic microbiome of Orobanche hederae reported that Orobanche leaves (scales) contain Acidobacteria, Proteobacteria, Verrucomicrobia and bacteria belonging to the Enterobacteriaceae, Pseudomonadaceae, and Rhizobiaceae ${ }^{12}$. The first report about seed endophytes of the holoparasitic $P$. ramosa reported a dominance of four bacterial phyla, i.e., Proteobacteria, Bacteroidetes, Actinobacteria, Firmicutes ${ }^{13}$. In another study on surface sterilized seeds of $P$. ramosa, culturable Brevibacterium frigoritolerans and Bacillus simplex were isolated ${ }^{14}$ (Table 1). 
Table 1

The endophytic bacterial phyla and bacterial species isolated from different tissues of holoparasitic plants

\begin{tabular}{|c|c|}
\hline Holoparasitic Plant & Endophytic Bacteria \\
\hline \multirow{6}{*}{$\begin{array}{l}\text { Phelipanche } \\
\text { aegyptiaca, } \\
\text { host plant: } \\
\text { tomato (Lycopersicum esculentum) }{ }^{11}\end{array}$} & Pre-haustorium stage \\
\hline & $\begin{array}{l}a, \beta, \gamma, \delta \text { Proteobacteria, Actinobacteria, } \\
\text { Flavobacteria, Sphingobacteria }\end{array}$ \\
\hline & Spider stage \\
\hline & $\begin{array}{l}a, \beta, \gamma, \delta \text { Proteobacteria, Flavobacteria, } \\
\text { Sphingobacteria, Firmicutes }\end{array}$ \\
\hline & Shoots \\
\hline & $\begin{array}{l}\text { a, } \beta, \text { y Proteobacteria, Actinobacteria, } \\
\text { Sphingobacteria, Clostridia, Flavobacteria, } \\
\text { Firmicutes }\end{array}$ \\
\hline \multirow{5}{*}{$\begin{array}{l}\text { Orobanche hederae, } \\
\text { host plant: } \\
\text { ivy (Hedera sp. })^{12}\end{array}$} & Roots \\
\hline & $\begin{array}{l}\text { Armatimonadetes, Bacteroidetes, } \\
\text { Proteobacteria, Actinobacteria, }\end{array}$ \\
\hline & Acidobacteria, Verrucomicrobia \\
\hline & Leaves \\
\hline & $\begin{array}{l}\text { Bacteroidetes, Actinobacteria, } \\
\text { Proteobacteria }\end{array}$ \\
\hline \multirow{4}{*}{$\begin{array}{l}\text { Phelipanche ramosa, } \\
\text { host plants: } \\
\text { oilseed rape (Brassica napus), hemp (Cannabis sativa), tomato (Solanum } \\
\text { lycopersicum), tobacco (Nicotiana tabacum), sunflower (Helianthus annuus), melon } \\
\text { (Cucumis melo) }{ }^{13,14}\end{array}$} & Seeds \\
\hline & $\begin{array}{l}\text { Proteobacteria, Actinobacteria, } \\
\text { Bacteroidetes, Firmicutes, }\end{array}$ \\
\hline & Brevibacterium friaoritolerans, Bacillus \\
\hline & simplex \\
\hline
\end{tabular}

Most of the seed associated bacteria are told to have an environmental origin and are important for adaptation of their host to environmental conditions ${ }^{15}$. In this way, the composition of seed-associated bacterial communities should be closely related to the soil bacterial communities and besides of the obligate endophytes, plant tissues can be colonized by soil bacteria as well. That is explained by possible migration of bacteria from the soil to the seeds ${ }^{15,16}$. Therefore, tissues of halotolerant plants also contain halophilic bacterial communities ${ }^{17}$. Recently, the interest in plant endophytes from ecosystems with harsh environmental conditions, especially saline soils has increased ${ }^{18,19}$.

At present, ample of endophytes have been isolated from different seeds of many wild and agricultural/sylvicultural herbaceous and woody plant species, including some holoparasitic species (Phelipanche ramosa) ${ }^{13,14,20-27}$. These endophytic microorganisms can improve plant tolerance against different biotic and abiotic stresses. In this way, they have the potential to mitigate the impacts of adverse conditions such as soil salinity, high concentrations of metals and climate change ${ }^{23,28-30}$. Recently, different bacterial phyla have been isolated from plants growing in arid and semiarid regions, like Larrea tridentate, from the desert plant Salsola ${ }^{31}$ and the saline wetland species Salicornia ${ }^{32}$. Furthermore, some authors argue that the bacterial phyla Proteobacteria, Bacteriodetes, Firmicutes, Planctomycetes, Actinobacteria, Fibrobacteres are common for halotolerant plants from arid and wetland soils ${ }^{24,31,32}$. Although, many researches highlight the importance of endophytes in plant health, the knowledge concerning communities of bacterial seed endophytes, especially about the microbiome of seeds of holoparasitic plant species is still limited ${ }^{11-13}$.

The major objective of our study was to compare the bacterial endo-microbiomes from seeds of the two above-mentioned holoparasitic plants Cistanche - C. armena and C. phelypaea - from saline habitats different in soil water status and to investigate how environmental conditions affect the diversity of the bacterial community of seeds of the two species. The other aim was to explore the physiological activities, several enzymatic and plants growth promoting (PGP) traits of the culturable seed endophytes that may have a role in plant responses and tolerance to abiotic stresses. 
The present study combined culture-dependent and molecular approaches. Molecular techniques were used to identify the culturable bacteria and to describe the diversity of the microbial communities in seeds of the two holoparasitic plant species. Some physiological, biochemical and PGP traits of the culturable endophytic bacterial strains were investigated. Also, the micromorphology of the seeds was studied. The micromorphological study of the examined seeds was crucial to select the appropriate method of surface sterilization, due to the unique structure of reticulated testa and the endothelium of the seed coat.

To the best of our knowledge that is the first report about bacterial seed endophytes of the holoparasitic plant species $C$. armena and $C$. phelypaea.

\section{Results}

\subsection{Seeds micromorphology}

C. armena. Seeds are dark brown, 541-1003 $\mu \mathrm{m}$ long, 347-631 $\mu \mathrm{m}$ wide with 1.1-2.3 length-to-width ratio and $164333-445987 \mu \mathrm{m}^{2}$ area. The shape is oblongoid to ovoid, rarely subrectangular. Seed ornamentation is constantly alveolate. The testae of the seeds have smooth thin outer periclinal walls that are adjacent to the inner periclinal with perforated (pitted) sculpture. The seed coat surface is formed by polygonal and isodiametric cells with different sizes, $41-159 \mu \mathrm{m}$ long and 33-96 $\mu \mathrm{m}$ wide with 1.0-3.1 length-to-width ratio. The number of cells along the seed longitudinal axis comprises 7-13 and in lateral view varies from 34 to 79 . The anticlinal walls are of slight depth with width 7.7-14.6 $\mu \mathrm{m}$ (Fig. 1a-b).

C. phelypaea. Seeds are black, seldom dark brown or lighter brown. The length is $510-951 \mu \mathrm{m}$, the width is $362-890 \mu \mathrm{m}$ with $1-1.6$ length-to-width ratio and $167726-596959 \mu \mathrm{m}^{2}$ area. Seeds are subglobose, often ovate, rarely subrectangular in outline. The seed coat surface is constantly alveolate with perforated (pitted)/striate test sculpturing of inter periclinal walls. The seed coat of the polygonal cells is more or less isodiametric with different sizes, $101-227 \times 75-160 \mu \mathrm{m}$ with 1.0-2.22 length-to-width ratio. The number of cells along the seed longitudinal axis ranges from 7 to 12 and in lateral view comprises from 35 to 61 . The anticlinal walls with remarkably depth with width 5.1-10.33 $\mu \mathrm{m}$. (Fig. 1c-d).

\subsection{Isolation of culturable endophytes from surface sterile seeds of Cistanche armena and C. phelypaea}

The nutrient media that were used for the isolation of bacterial endophytes had clear effects on growth rate and diversity (Table 2). Growth rates of bacteria and morphological diversity of colonies were the highest on rich media. On LB, MPA, THB and TSB 3-4 types colonies were dominating, while in others $(\mathrm{KB}, \mathrm{MHA})$ less different colonies were observed. Even less growth and morphological diversity were observed on MHA and KB. In addition to organic compounds, they contain $\mathrm{MgSO}_{4}, \mathrm{~K}_{2} \mathrm{HPO}_{4}$ or $\mathrm{Mg}^{2+}$ and $\mathrm{Ca}^{2+}$. However, the main difference with rich media was the concentration of sodium chloride. These media no contain $\mathrm{NaCl}$. The slowest growth was observed on the SAA and SAB media that contained only mineral compounds and $10 \mathrm{~g} \mathrm{I}^{-1} \mathrm{NaCl}$. 
Table 2

Composition of the bacterial growth media

\begin{tabular}{|c|c|c|c|c|c|c|c|c|}
\hline${ }^{a} g / L^{-1}$ & $\begin{array}{l}\text { LB } \\
)^{\left(\text {Himedia }^{m}\right.}\end{array}$ & $\begin{array}{l}\text { THB } \\
)^{\left(\text {Himedia }^{m}\right.}\end{array}$ & $\mathrm{SAA}^{84}$ & $\begin{array}{l}\text { KB } \\
\text { (NutriSelect@ } \\
\text { Basic) }\end{array}$ & $\begin{array}{l}\text { TSB } \\
)^{\left(\text {Himedia }^{m}\right.}\end{array}$ & $\mathrm{MPA}^{84}$ & $\begin{array}{l}\text { MHA } \\
)^{\left(\text {Himedia }^{m}\right.}\end{array}$ & $\begin{array}{l}\text { SAB } \\
\text { (NutriSelect }{ }^{\circledR} \\
\text { Plus) }\end{array}$ \\
\hline $\mathrm{K}_{2} \mathrm{HPO}_{4}$ & . & . & 2.0 & 1.5 & 2.5 & & . & 0.01 \\
\hline $\mathrm{Na}_{2} \mathrm{HPO}_{4}$ & . & 0.4 & . & . & & . & . & . \\
\hline $\mathrm{Na}_{2} \mathrm{CO}_{3}$ & . & 2.5 & . & . & . & & . & . \\
\hline $\mathrm{Mg}^{2+}$ & . & . & . & . & . & & $\begin{array}{l}0.020- \\
0.035\end{array}$ & . \\
\hline $\mathrm{Ca}^{2+}$ & . & . & & . & & . & $\begin{array}{l}0.045- \\
0.075\end{array}$ & . \\
\hline$(\mathrm{NH} 4)_{2} \mathrm{Fe}(\mathrm{SO} 4)_{2} \cdot 6 \mathrm{H}_{2} \mathrm{O}$ & . & . & . & . & . & & . & 0.11 \\
\hline $\mathrm{MgSO}_{4}$ & . & . & . & 1.5 & . & & . & 0.20 \\
\hline$\left(\mathrm{NH}_{4}\right)_{2} \mathrm{SO}_{4}$ & . & . & 2.0 & . & & . & . & . \\
\hline $\mathrm{MgSO}_{4} \cdot 7 \mathrm{H}_{2} \mathrm{O}$ & . & & 1.0 & & & . & . & \\
\hline $\mathrm{NaCl}$ & 10.0 & 2.0 & 3.0 & . & 5.0 & 5.0 & . & 10 \\
\hline Tryptone & 5.0 & . & . & . & & & . & . \\
\hline Dextrose & . & 2.0 & . & . & 2.5 & . & . & . \\
\hline $\begin{array}{l}\text { Papaic digest of } \\
\text { soyabean meal }\end{array}$ & . & . & . & . & 3.0 & . & . & . \\
\hline Pepton K & . & 20.0 & - & 20 & & 7,5 & 17.5 & \\
\hline Corn starch & . & . & 10.0 & . & . & - & 1.5 & . \\
\hline Beef heart & . & 3.1 & . & . & . & 5.0 & 2.0 & . \\
\hline Yeast extract & 5.0 & . & . & . & . & & . & . \\
\hline $\begin{array}{l}\text { Casein enzymic } \\
\text { hydrolysate }\end{array}$ & . & . & . & . & 17.0 & & . & . \\
\hline $\begin{array}{l}\text { the number of diverse } \\
\text { colonies (n) }\end{array}$ & $3-4$ & $3-4$ & 1 & $1-2$ & $3-4$ & $3-4$ & $1-2$ & 1 \\
\hline
\end{tabular}

2.2.1 Identification of culturable seed endophytes of Cistanche armena and C. phelypaea by 16S rRNA gene sequences

The identification of endophytes isolated from the seeds of $C$. phelypaea and $C$. armena was done based on 16S rRNA gene sequences. The nine isolated strains belong to the phylum Firmicutes (Table 3). The strains are members of the genera Bacillus, Oceanobacillus, Paenibacillus, Gracilibacillus (Table 3). Interestingly, that the strains CA4 (MW049354) isolated from the seeds of $C$. armena and CP4 (MW048514) from the seeds of $C$. phelypaea have $99.86 \%$ of similarity to Bacillus sp.: Bacillus australimaris strain MCCC1A05787, B. safensis strain NBRC100820 and B. pumilus strains NBRC12092. Bacillus australimaris (GenBank/EMBL/DDBJ) was described as a novel species by Yang Liu and colleagues in 2016, isolated from a shrimp farm of Zhangzhou city (China) and from a surface sediment sample of the South China Sea ${ }^{33}$. Bacillus safensis was first isolated from spacecraft surfaces (Mars Odyssey Orbiter $)^{34}$ and is highly similar to B. pumilus. 
Table 3

Bacterial endophytes isolated from seeds of Cistanche armena (CA) and C. phelypaea (CP) identified by 16S rRNA sequencing

\begin{tabular}{|lllll|}
\hline Simple Symbols & Accession & Bacterial species & Bacterial strain & Similarity \\
\hline CA3 & MW049354 & Bacillus licheniformis & strain DSM 13 & $100 \%$ \\
\hline CA4 & MW049355 & Bacillus australimaris & strain MCCC1A05787 & $99,86 \%$ \\
& & B. safensis & strain NBRC100820 & \\
\hline CA5 & MW049356 & Oceanobacillus oncorhynchi subsp. incaldanensis & strain 20AG & $99,80 \%$ \\
\hline CA8 & MW049357 & Bacillus gibsonii & strain DSM 8722 & $99,39 \%$ \\
\hline CA9 & MW049358 & Paenibacillus apiarius & strain DSM 5581 & $99,86 \%$ \\
\hline CA12 & MW049359 & Gracilibacillus alcaliphilus & strain SG103 & $99,87 \%$ \\
\hline CA15 & MW049360 & Bacillus firmus & strain NBRC 15306 & $98,78 \%$ \\
\hline CP4 & MW048514 & Bacillus australimaris & strain MCCC1A05787 & $99,86 \%$ \\
& & B. safensis & strain NBRC100820 & strains NBRC12092 \\
\hline CP12 & & B. pumilus & strain BCRC 17757 & $99,66 \%$ \\
\hline
\end{tabular}

\subsection{Physiological characteristics of isolated strains}

The isolated strains were tested for their tolerance to higher temperatures $\left(37^{\circ} \mathrm{C}, 42^{\circ} \mathrm{C}\right.$ and $\left.50^{\circ} \mathrm{C}\right)$, high concentrations of $\mathrm{NaCl}(10 \%$, $15 \%$ ) and broad $\mathrm{pH}$ ranges (4.0 to 11.0 ) (Table 4). For all strains, substantial growth was observed at $42^{\circ} \mathrm{C}$. In addition, strains $\mathrm{CA} 12$, CA4, CA3, CP4 and CP12 were growing at $50^{\circ} \mathrm{C}$, which allows to consider them as thermophilic. Strains CA5, CA9, CA8, however, showed negative growth rates at $50^{\circ} \mathrm{C}$. After $48 \mathrm{~h}$ of incubation at $25^{\circ} \mathrm{C}$ the bacterial colonies developed in all plates. This supports the endospore forming ability and real endophytic character of the isolated strains. The results of the seeds surface sterilization tests confirmed that the isolated strains were real endophytes and did not result from surface contamination of the seeds (Fig. 2). For the further experiments, $25^{\circ} \mathrm{C}$ was chosen as incubation temperature since this is the closest to a normal average soil temperature. Abundant growth was observed at high concentrations of $\mathrm{NaCl}(10 \%, 15 \%)$. Strains CA3, CA5, CA12 and CP4 demonstrated growth in the range of $3-15 \% \mathrm{NaCl}$, with an optimum at 5-10\%. Only strain $\mathrm{CA} 9$ did not develop at high concentrations of $\mathrm{NaCl}$; its optimal $\mathrm{NaCl}$ concentration in the medium was 3\%. Interestingly, strains CA4 and CP4 responded differently to high concentrations of NaCl. Wide ranges of adaptation and growth ability were observed at different pH (from pH 4.0 to pH 11.0). However, for all strains the best growth was observed at $\mathrm{pH}>7.0$ (Table 4). Combining all results, we can conclude that the isolated strains were endospore forming, halophilic and alkaliphilic. 
Table 4

Comparison of in vitro phenotypic traits of endophytic bacterial strains isolated from seeds of the holoparasitic plant species Cistanche armena (CA3, CA4, CA5, CA8, CA9, CA12) and C. phelypaea (CP4, CP12)

\begin{tabular}{|c|c|c|c|c|c|c|c|c|}
\hline \multirow[t]{2}{*}{ Characteristics } & \multicolumn{8}{|l|}{ Strains } \\
\hline & CA3 & CA4 & CA5 & CA8 & CA9 & CA12 & $\mathrm{CP} 4$ & CP12 \\
\hline Motility & + & + & + & + & + & + & + & + \\
\hline Gram reaction & + & + & + & + & + & + & + & + \\
\hline Spore forming & + & + & + & + & + & + & + & + \\
\hline $\begin{array}{l}\text { Temperature range (Topt) } \\
{ }^{\circ} \mathrm{C}\end{array}$ & $\begin{array}{l}25-50 \\
(42)\end{array}$ & $\begin{array}{l}25-50 \\
(42)\end{array}$ & $\begin{array}{l}25- \\
42(37)\end{array}$ & $\begin{array}{l}25- \\
42(37)\end{array}$ & $\begin{array}{l}25- \\
42(37)\end{array}$ & $\begin{array}{l}25-50 \\
(42)\end{array}$ & $\begin{array}{l}25-50 \\
(42)\end{array}$ & $\begin{array}{l}25-50 \\
(42)\end{array}$ \\
\hline $\mathrm{NaCl}$ range & $3.0-15.0$ & $3.0-10.0$ & $3.0-15.0$ & $3.0-10.0$ & $3.0-5.0$ & $3.0-15.0$ & $3.0-15.0$ & $3.0-10.0$ \\
\hline (0-20\%) (optimum) (\%) & $(5.0-10.0)$ & $(3.0-5.0)$ & $\begin{array}{l}(5.0- \\
10.0)\end{array}$ & $(3.0-5.0)$ & $(3.0)$ & $(3.0-10.0)$ & $(5.0-10.0)$ & $(3.0-5.0)$ \\
\hline \multirow[t]{2}{*}{ pH range (optimum) } & $6.0-11.0$ & $4.5-11.0$ & $4.0-11.0$ & $5.0-10.0$ & $4.0-9.0$ & $6.0-11.0$ & $5.0-11.0$ & $5.0-11.0$ \\
\hline & $(7.0-8.0)$ & $(7.0-9.0)$ & $(7.0-9.0)$ & $(7.0-8.0)$ & $(7.0-8.0)$ & $(7.0-9.0)$ & $(7.9-9.0)$ & $(7.0-8.0)$ \\
\hline Catalase & + & + & + & + & + & + & + & + \\
\hline Urease & - & - & - & + & + & - & - & - \\
\hline $\begin{array}{l}\text { Cellulose } \\
\text { hydrol. }\end{array}$ & + & + & - & + & + & + & + & + \\
\hline Protease & + & + & - & + & + & + & + & + \\
\hline Amylase & + & - & - & + & - & - & - & - \\
\hline Pectinase & + & - & - & - & + & - & - & + \\
\hline IAA Prod. $\left(\mathrm{mg} \mathrm{L}^{-1}\right)$ & 0.09 & 0.09 & 0.15 & 0.29 & 0.26 & 0.06 & 0.12 & 0.07 \\
\hline GA Prod. $\left(\mathrm{mg} \mathrm{L}^{-1}\right)$ & 2.78 & 1.68 & 2.07 & 1.87 & 2.13 & 2.20 & 1.42 & 1.94 \\
\hline $\begin{array}{l}\text { Phosphate } \\
\text { solubilization }\end{array}$ & - & + & + & - & - & + & - & - \\
\hline -. negative: +. positive: & & & & & & & & \\
\hline
\end{tabular}

\subsection{Selected biochemical activities of isolated strains}

The isolated strains were examined for their in vitro ureolytic and catalase activities, plant cell-wall degradation capacity (hydrolytic enzymes) and potential plant growth promoting traits (Table 4). Only strains CA8 and CA9 tested positive for urease activity, while all strains were positive for catalase activity. Strains CA3 and CA8 showed amylase activity and might thus be involved in seed germination. Strains CA3, CA9, CP12 demonstrated pectinase activity. Interestingly, most of the strains, except CA5, were exhibiting protease activity. With the exception of strains CA5 and CA8, all other strains could hydrolyze cellulose.

The isolated bacterial strains were also tested in vitro for some potential plant growth promoting (PGP) traits. Strains CA4, CA5 and CA12 could solubilize phosphate in NBRIP medium. The Bacillus strains CP4 and CA4 showed different phosphate solubilization reactions. Interestingly, the majority of the strains were able to produce IAA. In general, the production levels were low; strains CA8 and CA9 demonstrated the highest productions: $0.29 \mathrm{mg} \mathrm{L}^{-1}$ and $0.26 \mathrm{mg} \mathrm{L}^{-1}$ respectively. The highest GA production was achieved by strains CA3, CA5, CA9, CA12. The strains CA4 and CP4 showed the lowest GA production. This is in contrast to Hao et al. ${ }^{35}$ who reported that B. pumilus produced high concentrations of GA. Strains CA8 and CA9 produced high concentrations of both, IAA and GA.

Taking together all above mentioned data it is clear that strains CA3, CA8 and CA9 demonstrated the widest range of biochemical activities. The strains CA4, CA12 isolated from seeds of $C$. armena and strain CP4 from $C$. phelypaea seeds presented very similar 
biochemical activities. Strains CA4, CA5, CA12 possess PGP potential. Strain CA3, that has a high similarity to $B$. licheniformis DSM13 tested positive for all examined hydrolyzing enzymes. In contrast, strain CA5, isolated from seeds of $C$. armena and comparable to strain Oceanobacillus oncorhynchi subsp. incaldanensis 20AG, showed negative for all enzymes examined, except catalase. In addition, strain CA5 tested positive for phosphate solubilization and production of the phytohormones IAA and GA. To elucidate the effective benefits of these endophytic bacteria for their host plants, particularly for the seeds, seed germination and development of the seedling, more research is required.

\subsection{The seed-associated endophytic bacterial community compositions}

The number of paired raw Illumina readings for $C$. armena seeds was 107443 and 105028 for $C$. phelypaea seeds. The obtained numbers of readings after the filtering procedure were sufficient to carry out further stages of the analysis. It was anticipated to obtain minimal 100,000 paired readings for each of the tested samples. The readings obtained were filtered using the fastp tool (github.com/OpenGene/fastp) - the remaining sequences of the sequencing adapters and the low-quality readings were removed.

The Shannon-Wiener biodiversity indices for the seed endophytes of C. armena (CA) and C. phelypaea (CP) were 2.11 and 4.08 respectively (Fig. 3). 742 different OTUs were found in total: 352 OTUs for $C$. armena and 392 OTUs for $C$. phelypaea (Fig. 3). The proportions of bacterial counts significantly differ $z=72.0, p=0.035, r=0.43$ (medium effect size) between samples $C$. armena (median $=0.017$, IQR $0.00-0.098)$ C. phelypaea $($ median $=0.124$, IQR 0.037-0.809).

The taxonomy of the sequences was described primarily at the phylum level (Fig. 4). For the seeds of the two examined Cistanche populations 16 phyla, 323 genera and 710 species were determined. Ten phyla, 187 genera, and 331 species were identified from $C$. armena and 15 phyla, 216 genera, and 379 species in the seeds of $C$. phelypaea.

The Proteobacteria were the predominating phylum in the seeds of both examined plant populations (Table 5). The classes Alphaproteobacteria, Betaproteobacteria, Gammaproteobacteria, Deltaproteobacteria, as well as Acidithiobacillia were found but the Gammaproteobacteria clearly were the most abundant: $92.9 \%$ in seeds of $C$. armena and $61.8 \%$ in seeds of $C$. phelypaea. Also the phyla Actinobacteria, Bacteroidetes and Firmicutes were well represented. Other phyla constituted less than $0.22 \%$ (Table 5). The phyla Chlamydiae, Cyanobacteria, Deinococcus-Thermus, WS6, Fibrobacteres, Fusobacteria were only detected in seeds of $C$. phelypaea. Likewise, the phylum Gemmatimonadetes was only identified in seeds of $C$. armena. The phylum Firmicutes represented just $0.22 \%$ in seeds of $C$. armena but $9,75 \%$ in seeds of $C$. phelypaea. Nevertheless, only Firmicutes were isolated using culture medium: seven of the strains from the seeds of $C$. armena while only two Firmicutes strains could be isolated from the seeds of $C$. phelypaea. 
Table 5

The bacterial diversity of seed endophytic communities of holoparasitic plant species Cistanche armena and C. phelypaea in phylum and class levels (!) in percentages

\begin{tabular}{|c|c|c|}
\hline $\begin{array}{l}\text { Bacterial phylum* }(\%) \\
\text { Bacterial class** }(\%)\end{array}$ & C. armena & C. phelypaea \\
\hline Proteobacteria: & 94.7 & 79.67 \\
\hline Alpha-proteobacteria & 1.45 & 9.98 \\
\hline Beta-proteobacteria & 0.36 & 7.76 \\
\hline Gamma-proteobacteria & 92.91 & 61.77 \\
\hline Acidithiobacilla & 0 & 0.05 \\
\hline Actinobacteria: & 3.86 & 7.49 \\
\hline Actinobacteria-c & 3.78 & 7.06 \\
\hline Thermoleophilia & 0.02 & 0.07 \\
\hline Rubrobacteria & 0.03 & 0.02 \\
\hline Bacteroidetes: & 1.03 & 1.54 \\
\hline Sphingobacteriia & 0.82 & 0.38 \\
\hline Cytophagia & 0.20 & 0.61 \\
\hline Flavobacteria & 0.02 & 0.48 \\
\hline Firmicutes: & 0.22 & 9.75 \\
\hline Bacilli & 0.21 & 9.41 \\
\hline Acidobacteria: & 0.06 & 0.27 \\
\hline Vicinamibacter_c & 0.03 & 0.05 \\
\hline Chloroflexi & 0.03 & 0.56 \\
\hline Gemmatimonadetes & 0.03 & 0 \\
\hline Planctomycetes & 0.02 & 0.23 \\
\hline Saccharibacteria_TM7 & 0.01 & 0.14 \\
\hline Verrucomicrobia & 0.005 & 0.11 \\
\hline Chlamydiae & 0 & 0.02 \\
\hline Cyanobacteria & 0 & 0.06 \\
\hline Deinococcus-Thermus & 0 & 0.05 \\
\hline Fibrobacteres & 0 & 0.02 \\
\hline Fusobacteria & 0 & 0.07 \\
\hline WS6 & 0 & 0.02 \\
\hline \multicolumn{3}{|c|}{ !The classes represented less than $0.02 \%$ don't appeared in tabl } \\
\hline \multicolumn{3}{|c|}{ * Phylum level represented in bold } \\
\hline **Class level represented & & \\
\hline
\end{tabular}

At genus level (Fig. 5), most of the seed endophytes of C. armena belonged to Pantoea, Pseudomonas, Stenotrophomonas, Serratia and Streptomyces. In seeds of $C$. phelypaea the genus Pseudomonas dominated, followed by Kushneria, Acinetobacter, Pantoea, 
Sphingomonas, Massilia and Streptococcus. Other genera were present at abundances lower than $1 \%$ of the total seed endophytic community of both plant species.

In $C$. armena seeds, the most abundant OTU was Pantoea agglomerans representing $38.3 \%$ of the bacterial community, followed by Pseudomonas synxantha, Stenotrophomonas chelatiphaga, Serratia entomophila and Stenotrophomonas rhizophila. Other OTUs observed in abundances higher than $1 \%$ were Serratia_uc, Streptomyces lanatus, Pseudomonas granadensis. The seed endophytic community of $C$. phelypaea contained the following dominating OTUs: Pseudomonas coleopterorum, Pseudomonas graminis, Kushneria marisflavi, Pantoea agglomerans group, Acinetobacter Iwoffii, Bradyrhizobium japonicum, LMOA_s group, Kushneria indalinina, Acinetobacter schindleri, FM873692_s ${ }^{36}$, Pseudomonas fluorescens group, Streptococcus pneumoniae group, Duganella zoogloeoides group, Sphingomonas faeni group, Actinoplanes_uc, Sphingomonas adhaesiva group, Exiguobacterium aurantiacum group, Proteus mirabilis, Sphingomonas pruni group. Of all isolated strains, $0,9 \%$ from seeds of $C$. phelypaea and $0.4 \%$ from $C$. armena were unclassified species.

The relative abundances of the taxa composing the seed endophytic communities of both plant species at different taxonomic levels are presented in Supplementary Material 1.

LMOA_s group ${ }^{36}$ basionym of sp. nov. Pseudomonas ovata is a motile, Gram-negative and strictly aerobic bacteria from the genus Pseudomonas; it was first isolated from a skin ulcer ${ }^{37}$. Another noteworthy bacterial group is FM873692_s $S^{36}$ : Gram-negative unculturable representatives of Neisseriaceae, Betaproteobacteria species. Some species (Neisseria gonorrhoeae and N. meningitidis) are human pathogens, although some have been isolated from other mammals or environmental sources. Most of these organisms colonize mucosal surfaces, usually without causing pathology, therefore considered as part of the normal host microbiota ${ }^{38}$. As mentioned earlier, the bacterial strains CA4 and CP4 have high similarity to three strains from the NCBI database (Bacillus australimaris MCCC1A05787, B. safensis NBRC100820, B. pumilus NBRC12092). Also metagenomic analyses indicated the presence of the Bacillus pumilus group in seeds of both species $C$. armena $(0.02 \%)$ and $C$. phelypaea $(0.5 \%)$. In addition, the biochemical traits tests indicate the same. Therefore, it is very likely that the bacterial strains CP4 and CA4 are B. pumilus.

\section{Discussion}

The heterotrophic lifestyle of parasitic plants from the Orobanchaceae family led to several morphological, physiological and molecular adaptations and makes it an exciting group for study. Examples of such adaptation mechanisms are the production of large numbers of seeds and very specific conditions of germination ${ }^{9}$.

The seed surfaces of holoparasitic Cistanche species possess constantly alveolate ornamentation with perforated (pitted) sculpture formed by polygonal and isodiametric cells with different sizes. The quite coarse structure of the seed coat (Fig. 1) can hamper the seed sterilization process. The results we obtained applying generally used sterilization protocols ${ }^{39,40}$ was not always satisfying. We assume that the sterilizing agents could not always reach the deepest zones of the coarse seed surface. Finally, a combination of $70 \%$ ethanol and $10 \% \mathrm{H}_{2} \mathrm{O}_{2}$ with intense shaking showed to be adequate to remove all bacteria from the surfaces of $C$. armena and $C$. phelypaea seeds (Fig. 2).

To obtain cultivation of as many as possible of the endophytic bacterial strains, various rich and poor media were used (Table 2). The results indicated that growth rates of bacteria and morphological diversity of colonies were the highest on rich media. According to earlier studies, most endophytes have a soil or environmental origin, and the diversity and richness of bacterial communities correlates with the composition and $\mathrm{pH}$ of the soil ${ }^{41}$. Hence, organic compounds in rich media are essential for the growth of most microorganisms. Thus, on cultivation media with only inorganic compounds the growth and diversity were very limited. Besides, like plants, bacteria need macro- and microelements for their growth i.e. manganese, zinc, cobalt, molybdenum, nickel and copper which are critical for many metabolic processes ${ }^{42}$.

Very similar bacterial strains were isolated from the seeds of both plant species (Table 3). We obtained nine strains from surface sterilized seeds of $C$. armena and $C$. phelypaea belonging to the Bacillaceae family. All isolated endophytes are motile, Gram-positive and endospore forming (Table 4). These traits allow bacteria to survive in harsh environmental conditions or in dry seeds for a long period of time. This is important in case of holoparasites, because these seeds have to stay viable in the soil for several decades ${ }^{10}$. Our results confirm that spore forming Bacillus species are frequently isolated endophytes from seeds of plants growing in saline soils, solar salterns and salt marshes ${ }^{43-46}$. That the isolated strains are well adapted to the growing conditions of their host plants was 
confirmed by their physiological traits. All isolated endophytes showed to be halotolerant and alkaliphilic. Strains CA3, CA4, CA12, CP4, $\mathrm{CP} 12$ were also thermophilic. The thermophilic features of CA3, that has a high similarity to $B$. licheniformis DSM13, and B. pumilus (CA4, CP4) were also isolated from geothermal springs in Armenia, which confirms their adaptability to high temperatures ${ }^{47}$ and might have been marked as plant growth promoting ${ }^{48}$ of these strains.

The production of several enzymes and PGP traits of the culturable endophytic bacterial strains were investigated (Table 4). Interestingly, the production of one or more hydrolytic enzymes, especially cellulase and protease, was revealed for most of the isolated strains (Table 4). Cellulase and protease are involved in hydrolyzing cellulose and peptides and thus are 'instruments' for bacteria to get access to plant tissues and to colonize throughout the plant ${ }^{49,50}$. The production of amylase by strains CA3 $B$. licheniformis and CA8 $B$. gibsonii might be involved in seed germination and plant growth. During germination, amylase has a crucial role in the hydrolysis of endosperm starch, which provides energy for the developing roots and shoots ${ }^{51}$. According to Kaneko et al. ${ }^{52}$ the amylase production depends on phytohormones, particularly GA. Thus, gibberellins (GA) stimulate the synthesis and production of a-amylase. These phytohormones can induce a range of genes, which are necessary for the production of amylases including a-amylase, proteases and $\beta$-glucanases ${ }^{53,54}$. Therefore, it is not unexpected that these strains show relatively high levels of GA production (Table 4). Only for strain CA5 no activity of hydrolytic enzymes was detected, which concurs with existing literature. Production of enzymes involved in cell wall degradation was not reported before ${ }^{55}$. However, strain CA5, that shows a high similarity to Oceanobacillus oncorhynchi subsp. Incaldanensis AG20 tested positive for phosphate solubilization and production of the phytohormones IAA and GA. To elucidate the effective benefits of these endophytic bacteria for their host plants, particularly for the seeds, seed germination and development of the seedling, more research is required. Phytohormone production (IAA and GA) was confirmed in all isolates, and we speculate that production of such compound by bacteria might be beneficial for $C$. armena and $C$. phelypaea, particularly for absorption of more water and/or nutrients from their host plants in harsh environments.

The strains were also tested for urease activity. It is well-known that urease is an important cytosolic enzyme that is synthesized by living organisms, including plants and microorganisms. Generally, urea is used as a source of nitrogen and has a key role in pathogenesis of microorganisms, participates in the germination process and the nitrogen metabolism of plants ${ }^{56}$. The strains Paenibacillus apiarius $\mathrm{CA} 9$ and $P$. taichungensis $\mathrm{CP} 12$ demonstrated very similar biochemical traits, which allows to predict that they have a similar role in $C$. armena and $C$. phelypaea respectively. However, they demonstrate different urease activity (Table 4$)$. Bibi et al. ${ }^{57}$ showed that the urease activity might depends on the different levels of gene expression.

Altogether, the results presented above do not allow to elucidate the real beneficial potential of seed endophytes for holoparasitic plants. The majority of plant associated bacteria are unculturable, and it is often assumed that only $0.001-1 \%$ can be grown in laboratory conditions ${ }^{58}$. In order to obtain more information about the composition of the microbial communities (culturable and unculturable) in seeds of $C$. armena and $C$. phelypaea, molecular techniques were also used.

The results of the next generation sequencing analyses on Illumina MiSeq showed that the gram-negative Proteobacteria, and specifically the Gammaproteobacteria is an important taxon in seeds of both, $C$. armena and $C$. phelypaea. Many Gammaproteobacteria are halophilic ${ }^{59}$, thus their presence in the examined seeds is not surprising because of the natural habitats of both Cistanche species (Fig. 4, Table 5). Also Actinobacteria, Firmicutes and Bacteroidetes are well represented. These taxa were also isolated from seeds of Marama beans (Tylosema esculentum) growing in stressful environmental conditions and in poor-quality soils ${ }^{60}$. An overwhelming majority of seeds from different wild and commercial plant species, including some holoparasitic species are colonized by endophytes belonging to the phyla Proteobacteria, Actinobacteria, Firmicutes and Bacteroidetes ${ }^{13,16,60-63}$. The results about the seed endophytic microbiome of the parasitic Phelipanche ramosa ${ }^{13}$ together with the outcomes from the current study allow to assume that Proteobacteria, Actinobacteria, Bacteroidetes and Firmicutes are also common and abundant taxa in seeds of species of the Orobanchaceae (Table 1). The phylum Gemmatimonadetes was only found in seeds of $C$. armena $(0.03 \%)$. Different strains of Gemmatimonadetes were isolated from arid, semiarid and desert soils as well ${ }^{64}$. Besides of hereditary biochemical and morphological features desert plant show unique interactions with bacteria that colonize various plant parts. Well known, that the arid, semiarid and desert soils are nutrient poor, and the plants roots secrete organic compounds that attract bacteria which potentially can colonize the plant ${ }^{41}$. Some studies demonstrated that Gemmatimonadetes are more adapted to arid and semiarid soils, and at the same time the survival of Gemmatimonadetes may be inhibited in wet conditions. Therefore, exposure to drought may result in rapid colonization of arid and desert plants by these bacteria that established the relationship between moisture and microbial community structure ${ }^{64}$. Hence, considering the moisture requirements of $C$. phelypaea, Gemmatimonadetes are not expected to occur in the seeds of this 
species. Such information confirms our hypothesis, that water requirements and abiotic stresses influence the development of the seed bacterial community. Other bacterial phyla like Fibrobacteres, Chlamydiae, Cyanobacteria, Chloroflexi, Deinococcus-Thermus, WS6 were only present in the seeds of $C$. phelypaea. The phyla isolated from the seeds of $C$. phelypaea were recently also identified from sea water and anoxic marine sediments and were reported to have important ecological roles ${ }^{65}$. The Chloroflexi is a phylum including ecologically and physiologically diverse bacteria reported to occur in sediments, hot springs and methanogenic anaerobic sludge digesters ${ }^{66}$, but not from plant seeds. Another bacterial phylum, Deinococcus-Thermus, comprises extremophiles highly resistant to abiotic stresses ${ }^{67}$ and was recently found in seeds of different plant species ${ }^{25,68}$. The phylogenetic group WS6 is unexplored, widely spread in some environments, and detected mostly in anaerobic sediments. According to Dojka et al. ${ }^{69}$ they may possess some undiscovered biochemical and metabolic novelties and important biogeochemical roles. Our prediction about the relationship between environmental conditions and endophytic bacterial diversity is supported by previous findings ${ }^{41,70}$. Investigations of the desert plants Tribulus terrestris, Zygophyllum simplex, Panicum turgidum and Euphorbia granulata from the Namib Desert and Saudi Arabia showed that they harbor a very similar endomicrobiome where the dominating bacterial phyla are Proteobacteria, Bacteroidetes, Actinobacteria and Firmicutes also ${ }^{41,71,72}$. On the other hand, Eida et al. ${ }^{71}$ reported that they possess various biochemical traits and salinity stress tolerance. The Actinobacteria of the genera Streptomyces, Micromonospora, Nocardia, and Amycolatopsis are mainly present in seeds of $C$. armena. Huang et al. ${ }^{73}$ previously described these genera in arid plants.

The seeds of $C$. phelypaea and $C$. armena are colonized by mostly unculturable, Gram negative, halotolerant bacteria that have an environmental origin. Some bacterial species were also isolated from other plants or soils, for instance, Serratia marcescens, Sphingomonas hylomeconis, Bacillus pumilus group, Bacillus cereus, Proteus mirabilis, Microbacterium halotolerans group, sp. nov. Kushneria spp, sp. nov. Halomonas stenophila Tamlana crocina, sp. nov. ${ }^{24,74,75}$. In seeds of $C$. armena Novosphingobium was determined. This genus was also identified by lasur Kruh et al. ${ }^{11}$, in Phelipanche aegyptiaca and was reported as specific endophytes for this plant species.

Although, the seed endophytic microbiomes of $C$. armena and $C$. phelypaea that originate from totally different geographical locations and environmental conditions comprise a high number of common bacterial taxa, there were, however, sizable differences between the compositions and diversities of both microbiomes. The Shannon-Wiener biodiversity index value was 2.11 for $C$. armena and 4.08 for C. phelypaea which means a higher diversity in seeds of $C$. phelypaea (Fig. 3). Considering that $C$. armena grows under more adverse abiotic stresses (salinity, drought and high temperature) it is predictable that the seeds are colonized by a less diverse microbiome. $C$. phelypaea is growing in saline but wet environmental conditions and its seeds harbor a more diverse microbiome, which could be expected. Generally, seeds do not provide favorable conditions for microbial growth and show low numbers of bacteria ${ }^{76}$. It was also shown that the composition of the seed endophytic community is changing during the seed maturation process and seeds are containing mainly bacteria adapted to survive in harsh abiotic conditions or that are able to stimulate the host plant metabolism for responses to abiotic stresses ${ }^{77-79}$.

\section{Conclusion And Future Opportunities}

We investigated and compared the endophytic bacterial communities of the seeds of two holoparasitic Cistanche species. A protocol for seed surface sterilisation was fine-tuned. Sixteen phyla, 323 genera and 710 bacterial species were identified, mainly Gram negative, halotolerant bacteria with an environmental origin. In the seeds of both species-specific bacteria were identified that are adapted to the growing conditions of their respective host plants. However, also some unclassified and unexplored taxonomic groups were found in the seeds of both plants. The findings allow us to assume that the bacterial endophytes of the seeds of both species show common physiological characteristics required to cope with the abiotic stress factors that are common to both locations - high temperatures and high salt concentrations.

The cultivable seed endophytes from $C$. armena and $C$. phelypaea were rather similar, notwithstanding the big distances between their growth habitats - Armenia and Portugal. Our results corroborate that Bacillus species are commonly isolated endophytes from plants growing on saline and arid soils. The Paenibacillus strains from both plant species demonstrate similar biochemical traits. Our results confirm the presence of Novosphingobium in holoparasitic plants.

Summarizing, the results obtained in the present work from the culturable seed endophytes indicate that some biochemical and enzymatic traits of the isolated strains might be favorable for supporting plant responses to abiotic stresses. In spite of that, the obtained results do not allow yet to designate the real beneficial potential and ecological significance of these seed isolates for the

Page 12/25 
holoparasitic plant species $C$. armena and $C$. phelypaea, especially concerning their role in seed germination and the physiology of host plant infection by parasitic plants. However, genome sequencing, extensive bioinformatic analysis and identification of stress responding genes, and also identification of metabolic and enzymatic activity of the isolated bacteria can elucidate some aspects of interaction with their host, their role in seed germination and promotion of plant growth.

\section{Materials And Methods}

\subsection{Species studied and plant material}

For our study, we used seeds of two species from the genus Cistanche Hoffmanns. \& Link (Orobanchaceae), from distant locations in Portugal vs Armenia, both from saline habitats, but differing in soil water status: flooded coasts vs semi-deserts.

Cistanche armena (K. Koch) M.V. Agab. as an endemic, critically endangered species, known only from the Ararat and Armavir provinces in central Armenia, in the Arax River valley and the foot of Mount Ararat, at the border between Armenia, Turkey and Nakhchivan 80,81 . Seeds of the endemic species $C$. armena were collected in June 2017 in Armenia, Ararat province, Arax River valley and foot of Mount Ararat, NW of Lusarat village, near the Khor Virap monastery (39 $53^{\prime \prime} 01^{\prime} \mathrm{N}, 44^{\circ} 34^{\prime \prime} 49^{\prime} \mathrm{E}$ ). This locality is one of the hottest and extremely arid regions of Armenia (the average precipitation during summer does not exceed $30 \mathrm{~mm}$ ), in a semi-desert, with sandy, saline soils with halophytic vegetation, at about 820-840 m above sea level. C. armena parasitizes Alhagi maurorum (Fabaceae), and Salsola dendroides (Chenopodiaceae) (Fig. 6c-d).

The second species, Cistanche phelypaea (L.) Cout. shows a Mediterranean Basin distribution and is endemic to the west coast of the Iberian Peninsula, in Portugal and Spain ${ }^{82}$. Seeds of C. phelypaea were collected in April 2012 in Portugal, Algarve region, in the southwestern part of Alvor, in the estuary of the Rio Alvor to the Atlantic Ocean, at about $10 \mathrm{~m}$ above sea level $\left(37^{\circ} 07^{\prime} 48.0^{\prime \prime} \mathrm{N}\right.$ $\left.8^{\circ} 37^{\prime} 12.0^{\prime \prime} \mathrm{W}\right)$. The study area is periodically flooded, and consists of coastal salt marshes, with sandy-silty zones, and a halophytic community dominated by chamaephytes, including host species of $C$. phelypaea, like Arthrocnemum macrostachyum, Sarcocornia fruticosa, Suaeda vera (Amaranthaceae), and Limoniastrum monopetalum (Plumbaginaceae) (Fig. 6a-b).

Seeds were collected from mature fruits, per 10 specimens for both species, and dried under natural conditions. Species were identified and seeds collected by Renata Piwowarczyk and herbarium materials were deposited in the Herbarium of the Jan Kochanowski University in Kielce (KTC), Poland. Field studies, including the collection of plant and seeds material was compiled with relevant local, institutional, national, and international guidelines, permissions and legislation.

\subsection{Microscopic observation and morphometric analysis of seeds}

General seed morphology was studied using an Axio Zoom.V16 Stereo Zoom system (Carl Zeiss, Germany) in bright field illumination (objective lenses PlanApo Z 1.5x, FWD = $30 \mathrm{~mm}$ ) and processed in ImageJ software using Fiji macros. The terminology of seed surfaces is taken from Barthlott ${ }^{83}$, and Piwowarczyk et al. ${ }^{5}$. For each species, at least 30 seeds were examined, and quantitative and qualitative morphological characteristics were determined several times for each seed.

\subsection{Seed surface-sterilization method and cultivation conditions of culturable seed endophytic bacteria}

The aim of the seed surface sterilization was to obtain only endophytic bacterial communities. $50 \mathrm{mg}$ seeds of each sample were transferred into Eppendorf tubes and were submersed in 70\% ethanol (EtOH) and vortexed for 60 sec (VELP Scientifica), followed by a $10 \% \mathrm{H}_{2} \mathrm{O}_{2}$ aqueous solution with intense vortexing at $8000 \mathrm{rpm}$ for 3-4 min. Finally, sterile seeds were rinsed 4-5 times with sterile deionized water. The surface sterile undamaged (marked F) and mechanically homogenized (marked $\mathrm{H}$ ) seeds were plated on previously prepared Petri dishes (Fig. 2). Observations were done after $48 \mathrm{~h}$ of incubation at $25^{\circ} \mathrm{C}$. Only bacterial colonies obtained from crushed seeds (marked $\mathrm{H}$ ) were selected for further experiments and were placed onto growth media (autoclaved at $121^{\circ} \mathrm{C}$ for 20 min), with pH $7.0 \pm 0.1$ (Fig. 2). In order to obtain an as complete overview of the culturable community as possible different bacterial growth media were used with peptones, corn starch, dextrose, papaic digest of soybean meal, enzymes, yeast extract, and components of animal origin Meat Peptone Agar (MPA), Tryptic Soy Broth (TSB), Starch Ammonium Agar (SAA), Todd-Hewitt broth (THB), King's B (KB), Mueller Hinton Agar (MHA), Sabouraud Agar (SAB) with minor changes) (Table 2). SAA medium aims to select for inorganic nitrogen using bacteria, MPA is used for isolation of organic nitrogen using bacteria ${ }^{84}$. Because of the particular natural habitats of the halophytes $C$. armena and $C$. phelypaea, media were selected with specific compositions of micro- and macronutrients like they occur

Page $13 / 25$ 
in the soils the host plants are growing on. C. armena grows in dry, saline, mainly clayey alkaline soils with pH 9-11 and ESP $>20 \%$ (ESPExchangeable Sodium Percentage) ${ }^{85}$; C. phelypaea is flourishing in sandy-silty zones of coastal salt marshes.

For further experiments single, morphological diverse colonies were picked. The chosen colonies were cultivated several times to get pure colonies with identical shape, color, size, and time of growth. These pure strains were used for DNA isolation. To verify purity of the colonies BOX PCR was used. The endophytic bacterial isolates were marked CA3, CA4, CA5, CA8, CA9, CA12, CA15 for C. armena and $\mathrm{CP} 4, \mathrm{CP} 12$ for $C$. phelypaea.

\subsection{DNA isolation and polymerase chain reaction}

DNA from the cultivable bacterial strains was isolated using Genomic Mini AX Bacteria Spin kits (A\&A Biotechnology, Gdynia, Poland) according to the manufacturer's instructions. Genomic DNA was checked for quality using $1 \%$ gel electrophoresis agarose. Qualitative and quantitative assessment of the isolated DNA was provided. To assess the amount of matrix delivered, measurements were also made using a GelVue UV Transilluminator (Gbox Chemi16 Gel Imaging System Unit SYNGENE, UK, Cambridge).

\subsubsection{S rRNA gene fingerprinting}

To confirm the presence of bacteria, PCR amplification of 16S rDNA gene fragments using primers 27F (5AGAGTTTGATCMTGGCTCAG-3) and 1492R (5-GGTTACCTTGTTACGACTT-3) was performed. The amplification reaction was carried out on an ABI 9700 thermocycler (Life Technologies) and thermostable OptiTaq polymerase from EURx (EURx Gdansk, Poland). The PCR reaction cycling conditions were hot start that consisted of initial denaturation at $95^{\circ} \mathrm{C}$ for 3 min followed by 30 cycles including denaturation at $95^{\circ} \mathrm{C}$ for $15 \mathrm{sec}$, annealing at $55^{\circ} \mathrm{C}$ for $15 \mathrm{sec}$, extension at $72^{\circ} \mathrm{C}$ for $90 \mathrm{sec}$. The final stage was incubation at $72^{\circ} \mathrm{C}$ for 2 min, then cooling at $10^{\circ} \mathrm{C}$. Positive amplification results were obtained for all samples tested. PCR products were purified with ExoSap and sequenced using the BigDye ${ }^{T M}$ Terminator v3.1 Cycle Sequencing Kit and ABI3730xI (Applied Biosystems, USA) genetic analyzer and specific primers. Contigs were successfully obtained by assembling the specific reported primers (readings from bacterial $16 \mathrm{~S}$ rRNA gene-specific primers: $341 \mathrm{~F}, 518 \mathrm{R}$ and $928 \mathrm{~F}$ ) to give a consensus sequence. The $16 \mathrm{~S}$ rRNA gene analysis was performed in the Institute of Biochemistry and Biophysics PAS in the Laboratory of DNA Sequencing and Oligonucleotide synthesis (oligo.pl). The obtained sequence consensus was compared to the NCBI-GenBank database using the program BLAST. The gene sequences were deposited in the NCBI GenBank (http://www.ncbi.nlm.nih.gov/) under the accession numbers MW049354 through MW049360 for the bacterial seed endophytes of $C$. armena and MW048514, MW048515 for those of $C$. phelypaea (Table 3).

\subsubsection{Phylogenetic tree of bacterial endophytes}

A maximum likelihood phylogenetic tree based on nearly complete 16S rRNA gene sequences was made (Fig. 7), showing the relationships between the nine bacterial strains isolated from seeds of $C$. armena and $C$. phelypaea and closely related strains from the database: Bacillus spp., Oceanobacillus, Gracilibacillus and Paenibacillus spp. The evolutionary history was inferred using the Neighbor-Joining method ${ }^{86}$. Evolutionary analyses were conducted in MEGA $X^{87}$.

\subsection{Identification of the total endophytic bacterial community}

For identification of the total (cultivable and uncultivable) bacterial community, $50 \mathrm{mg}$ of seeds was transferred to sterile $1.5 \mathrm{ml}$ eppendorf tubes, and $1 \mathrm{ml} 0.85 \%$ sterile $\mathrm{NaCl}$ solution was added followed by shaking on a vortex $(8,000 \mathrm{rpm})$ at $21^{\circ} \mathrm{C}$ for $2.5 \mathrm{~h}$. Subsequently, the washed seeds were kept at $4^{\circ} \mathrm{C}$ for $15 \mathrm{~min}$. Before rinsing with sterile double distilled water, the samples were centrifuged for $30 \mathrm{sec}$ at 12,000 rpm (13,400 x g). The washing process was repeated with decreasing the time of shaking $(2 \mathrm{~h}, 1.5 \mathrm{~h}$, $60 \mathrm{~min}, 45 \mathrm{~min}$ and $30 \mathrm{~min}$ ). The samples were centrifuged $30 \mathrm{sec}$, then rinsed with sterile double distilled water, then kept at $4^{\circ} \mathrm{C}$ for 15 $\mathrm{min}$. The rinsing procedure was repeated 3 times. To exclude the presence of DNA from bacteria present on the seed coat, PCR was performed on the last rinsing water. After verifying the effectiveness of the sterilization protocol, the sterile homogenous seed suspension was used for DNA extraction using the Genomic Mini AX Stool Spin (A\&A Biotechnology) according to manufacturer's instructions. The quality and quantity of the DNA was examined by electrophoresis on a $1 \%$ agarose gel. Amplified products were resolved in $1.0 \%(\mathrm{w} / \mathrm{v})$ agarose gel in a Tris-acetate-EDTA buffer (TAE) and visualized under UV light (Syngene) after staining with ethidium bromide.

\subsubsection{Amplification of the 16S rRNA gene fragment and preparation of the next generation sequencing library}

Page $14 / 25$ 
The diversity of the endophytic bacterial communities of the seeds of $C$. armena and $C$. phelypaea has been assessed by highthroughput sequencing of the 16S rRNA amplicon based on Illumina Sequencing based on the V3 and V4 hypervariable region of the 16S rRNA gene by using paired-end sequencing on an Illumina MiSeq device. In order to amplify a fragment of the 16S rRNA gene in the samples, specific primers were used ${ }^{88}$ :

16S_V3-F 357F: 5- TCGTCGGCAGCGTCAGATGTGTATAAGAGACAG- CCTACGGGNGGCWGCAG -3

16S_V4-R 785R: 5-GTCTCGTGGGCTCGGAGATGTGTATAAGAGACAG- GACTACHVGGGTATCTAATCC-3

The sequences for the amplification of the 16S rRNA gene fragment are underlined. The amplification reaction was performed in an $\mathrm{ABI}$ 9700 thermocycler (Life Technologies) using the Kapa HiFi PCR Mix thermostable polymerase (Roche). PCR reaction conditions: $95^{\circ} \mathrm{C}-2$ min, $95^{\circ} \mathrm{C}-15 \mathrm{~s}, 60^{\circ} \mathrm{C}-10 \mathrm{~s}, 72^{\circ} \mathrm{C}-30 \mathrm{~s}$. Steps $2-4$ repeated 25 times $72^{\circ} \mathrm{C}-7 \mathrm{~min}, 10^{\circ} \mathrm{C}$-cooling. All samples were positive for amplification. $\sim 450 \mathrm{bp}$ amplification products were obtained. DNA was purified using Ampure XP magnetic beads (Beckman Coulter) and indexed by second-order PCR. The FASTP (github.com/OpenGene/fastp) tool was used for sequence filtration and analysis of sequenced data. Indexing (adding a specific index individually for each of the tested samples) allowed for pooling of the samples and their simultaneous preparation for NGS sequencing with the help of specific P5 and P7 adapters at the 5'ends of the amplicons. OTU clustering and classification at several taxonomic levels, kingdom, phylum, class, order, family, genus and species were performed for both examined seed types. The next generation sequencing was performed by the Laboratory of DNA Sequencing and Oligonucleotide synthesis of the Institute of Biochemistry and Biophysics PAS (oligo.pl). The gene sequences have been submitted to the NCBI Sequence Read Archive under the BioProject ID: PRJNA704552, Submission ID: SUB9080848.

\subsection{Statistical analysis}

The significance of differences in the numbers of OTU/genera was tested by using the Independent Sample T-Test by Jamovi Version 1.6 (2020, https://www.jamovi.org/). Due to the lack of normal distribution of the variables, comparisons among the $C$. armena and $C$. phelypaea for the phylum value were tested with the Mann-Whitney $\mathrm{U}$ test ( $\mathrm{p}$-value $<0.05$ was considered significant).

\subsection{Physiological traits of culturable bacterial seed endophytes isolated of C. armena and $C$. phelypaea}

The culturable bacterial seed endophytes were investigated for their tolerance to temperature $\left(25-50^{\circ} \mathrm{C}\right)$, salinity $(0-20 \% \mathrm{NaCl})$ and $\mathrm{pH}$ (4.0-11.0). The LB (Luria Broth) agar with $\mathrm{pH} 7.0 \pm 0.1$ was used as control for all tests.

\subsection{Biochemical activities of cultivable bacterial seed endophytes isolated of $C$. armena and $C$. phelypaea}

\subsubsection{Motility ${ }^{89}$ and catalase activity ${ }^{90}$ were tested according to the protocols mentioned in the papers.}

\subsubsection{Ureolytic activities: The hydrolysis of urea was tested on modified Christensen medium. As a control Proteus vulgaris(ATCC13315) ${ }^{91}$ strain was used.}

\subsubsection{Hydrolytic enzymes}

Cellulose hydrolyzing ability. For determination of the cellulose-degrading ability of bacteria which use cellulose as carbon source, the cellulose Congo-Red agar medium ${ }^{92}$ was employed. The cellulose Congo-Red agar medium without cellulose was used as a control. Discoloration of Congo-Red demonstrates a positive cellulose-degrading reaction.

\section{Protease}

Protease activity was tested on skim milk agar plates ${ }^{93}$. After $72 \mathrm{~h}$ incubation at $25^{\circ} \mathrm{C}$ clean zones around colonies were observed. 
a-amylase: a-amylase activity was determined on Starch Agar. After $48 \mathrm{~h}$, an iodine solution was used as an indicator. A clean zone around the colony indicated hydrolysis of starch and amylase production ability of bacteria ${ }^{94}$.

\section{Pectinase}

Pectinase activity was observed in basal medium. Clear zones diluted with Gram's iodine solution and dark blue background indicated pectinase production ${ }^{95}$.

\subsubsection{Synthesis of plant growth promoting substances}

\section{Indole-3-acetic acid (IAA) synthesis}

Bacterial isolates were incubated in dark at $28^{\circ} \mathrm{C}$ in LB (Himedia ${ }^{\mathrm{TM}}$ ) liquid medium with tryptophan. The concentration of produced IAA was determined spectrophotometrically at $520 \mathrm{~nm}^{96}$.

\section{Gibberellic acid (GA) production (Borrow method)}

Bacterial isolates were incubated in darkness onto Nutrient Broth medium at room temperature for 7 days. Absorbance was measured at $254 \mathrm{~nm}^{96}$.

\section{Phosphate solubilization}

The phosphate solubilization ability was tested in NBRIP (National Botanical Research Institute's Phosphate growth medium) medium for soil bacteria ${ }^{97}$. After incubation, the plates were checked for clean clear halos around the colonies. Pseudomonas sp. was chosen as a control.

All physiological, biochemical and PGP tests were performed at least two times.

\section{Declarations}

\section{Data availability statement.}

We declare that all data on the basis of which this manuscript was created are publicly available and disseminated in the manuscript itself or as supplementary materials.

\section{Acknowledgements}

Publication was prepared under "Partnership agreement governing the joint supervision and awarding of a doctorate diploma between Jan Kochanowski University in Kielce (Poland) and Hasselt University (Belgium)" (K.P.). Thank Dr. Yuliya Krasylenko for taking photographs in ZOOM microscope.

\section{Author contributions}

Conceptualization, K.P; Originator of the research topic, R.P.; Field research, R.P.; Methodology, K.P, W.K., J.V, K.R., R.P.; Resources, R.P., W.K., K.P.; Writing-original draft preparation, K.P., R.P, K.R.; Writing-review and editing, R.P., W.K., J.V.; Visualization, K.P., R.P, K.R. All authors read and approved the final manuscript.

\section{Funding}

The author acknowledges financial support through the project „Development Accelerator of the Jan Kochanowski University of Kielce”, co-financed by the European Union under the European Social Fund, with no. POWR.03.05.00-00-Z212/18 (K.P.). This work was supported by grants from Jan Kochanowski University Kielce Poland SUPB.RN. 21.235 (W.K.; K.P.). The field research in this study in Armenia was partially financed by the National Geographic grant GEFNE 192-16 (2017) (R.P.) and the Research Project 666065 (2019) (K.R.).

\section{Competing Interests}


The authors declare that the research was conducted in the absence of any commercial or financial relationships that could be construed as a potential conflict of interest.

\section{References}

1. Nickrent, D. L. Parasitic angiosperms: How often and how many? Taxon69(1), 5-27. https://org/10.1002/tax.12195 (2020).

2. Schneider, A. C. \& Moore, A. J. Parallel Pleistocene amphitropical disjunctions of a parasitic plant and its host. J. Bot.104(11), 1745-1755. https://doi.org/10.3732/ajb.1700181 (2017).

3. Eriksson, O. \& Kainulainen, K. The evolutionary ecology of dust seeds. Plant Ecol. Evol. Syst.13(2), 73-87. https://doi.org/10.1016/j.ppees.2011.02.002 (2011).

4. Piwowarczyk, R. Seed productivity in relation to other shoot features for endangered parasitic plant Orobanche picridis W. Schultz (Orobanchaceae). Pol. J. Ecol.61(1), 55-64 (2013).

5. Piwowarczyk, R., Ruraż, K., Krasylenko, Y., Kasińska, J. \& Sánchez-Pedraja, Ó.Seed micromorphology of representatives of holoparasitic Orobanchaceae genera from the Caucasus region and its taxonomic significance. Phytotaxa 432(3), 223-251. https://org/10.11646/phytotaxa.432.3.1 (2020).

6. Joel, D. M. et al. Seed ultrastructure and water absorption pathway of the root-parasitic plant Phelipanche aegyptiaca (Orobanchaceae). Bot.109(1), 181-195. https://doi.org/10.1093/aob/mcr261 (2012).

7. Teryokhin, E. S. \& Kravtsova, T. I. Carpological and anatomical analysis of the genus Phelipanche (Orobanchaceae). Botaniceskij Zhurnal (Moscow \& St. Petersburg) 68(11), 1488-1496 (1983).

8. Teryokhin, E. S. Weed broomrapes: systematics, ontogenesis, biology, evolution. (Aufstieg-Verlag, Landshut,1997).

9. Yoneyama, K. et al. Strigolactones, host recognition signals for root parasitic plants and arbuscular mycorrhizal fungi, from Fabaceae plants. New Phytol. 179(2), 484-494. https://doi.org/10.1111/j.1469-8137.2008.02462.x (2008).

10. Joel, D. M. et al. Biology and management of weedy root parasites. Rev.33, 267-349. https://doi.org/10.1002/9780470168011.ch4 (2007).

11. lasur Kruh, L. et al. Host-parasite-bacteria triangle: the microbiome of the parasitic weed Phelipanche aegyptiaca and tomatoSolanum lycopersicum (Mill.) as a host. Plant Sci.8, 269. https://doi.org/10.3389/fpls.2017.00269 (2017).

12. Fitzpatrick, C. \& Schneider, A. Unique bacterial assembly, composition, and interactions in a parasitic plant and its host. Exp. Bot.71(6), 2198-2209. https://doi.org/10.1093/jxb/erz572 (2020).

13. Huet, S. et al. Populations of the parasitic plant Phelipanche ramosa influence their seed microbiota. Plant Sci. 11, 1075. https://doi.org/10.3389/fpls.2020.01075 (2020).

14. Durlik, K., Żarnowiec, P., Piwowarczyk, R. \& Kaca, W. Culturable endophytic bacteria from Phelipanche ramosa (Orobanchaceae) seeds. Seed Sci. Res. 31(1), 69-75. https://doi.org/10.1017/S0960258520000343 (2021).

15. Frank, A. C., Saldierna Guzmán, J. P. \& Shay, J. E. Transmission of bacterial endophytes. Microorganisms5(4),70. https://org/10.3390/microorganisms5040070 (2017).

16. Sánchez-López A.S. et al. Wild flora of mine tailings: perspectives for use in phytoremediation of potentially toxic elements in a semi-arid region in Mexico. J. Phytoremediation17, 476-484. https://doi.org/10.1080/15226514.2014.922922 (2015).

17. Etesami, H. \& Beattie, G. A. Mining halophytes for plant growth-promoting halotolerant bacteria to enhance the salinity tolerance of non-halophytic crops. Microbiol.9, 148. https://doi.org/10.3389/fmicb.2018.00148 (2018).

18. Hrynkiewicz, K., Patz, S. \& Ruppel, S. Salicornia europaea as an underutilized saline-tolerant plant inhabited by endophytic diazotrophs. J. Adv. Res.19, 49-56. https://doi.org/10.1016/j.jare.2019.05.002 (2019).

19. Manasa, K. M., Vasanthakumari, M. M., Nataraja, K. N. \& Uma Shaanker, R. Endophytic fungi of salt adapted Ipomea pes-caprae L. $R$. Br. their possible role in inducing salinity tolerance in paddy (Oryza sativa ).Curr. Sci.118(9), 1448-1453. (2020).

20. Ulrich, K., Ulrich, A. \& Ewald, D. Diversity of endophytic bacterial communities in poplar grown under field conditions. FEMS Microbiol. Ecol.63(2), 169-180. https://org/10.1111/j.1574-6941.2007.00419.x (2008).

21. Truyens, S., Weyens, N., Cuypers, A. \&Vangronsveld, J. Changes in the population of seed bacteria of transgenerationally Cdexposed Arabidopsis thaliana. Plant Biol.15(6), 971-981. https://org/10.1111/j.1438-8677.2012.00711.x (2013).

22. Truyens, $\mathrm{S}$. et al. The effect of long-term $\mathrm{Cd}$ and $\mathrm{Ni}$ exposure on seed endophytes of Agrostis capillaris and their potential application in phytoremediation of metal-contaminated soils. J. Phytoremediation16(7-8), 643-659.

Page $17 / 25$ 
https://doi.org/10.1080/15226514.2013.837027 (2014).

23. Truyens, S. et al. The effects of the growth substrate on cultivable and total endophytic assemblages of Arabidopsis thaliana. Plant Soil405(1/2), 325-336. https://org/10.1007/s11104-015-2761-5 (2016).

24. Asaf, S. et al. Bacterial endophytes from arid land plants regulate endogenous hormone content and promote growth in crop plants: an example of Sphingomonas sp. and Serratia marcescens. Plant Interact.12(1), 31-38. https://doi.org/10.1080/17429145.2016.1274060 (2017).

25. Sánchez-López, A.S. et al. Seed endophyte microbiome of Crotalaria pumila unpeeled: identification of plant beneficial Methylobacteria. J. Mol. Sci.19(1), 291. https://doi.org/10.3390/ijms19010291(2018).

26. Glassner, H., Zchori-Fein, E., Yaron, S., Sessitsch, A., Sauer, U. \& Compant, S. Bacterial niches inside seeds of Cucumis meloPlant Soil422, 101-113. https://doi.org/10.1007/s11104-017-3175-3 (2018).

27. Compant, S., Samad, A., Faist, H. \& Sessitsch, A. (2019). A review on the plant microbiome: Ecology, functions, and emerging trends in microbial application. Adv. Res. 19, 29-37. https://doi.org/10.1016/j.jare.2019.03.004

28. Hallmann, J., Quadt-Hallmann, A., Mahaffee, W. F. \& Kloepper, J. W. Bacterial endophytes in agricultural crops. J. Microbiol. 43(10), 895-914. https://doi.org/10.1139/m97-131 (1997).

29. Manjunatha, B. S. et al. Evaluation of endophytic bacteria for their influence on plant growth and seed germination under water stress conditions. J. Curr. Microbiol. App. Sci.6(11), 4061-4067. https://doi.org/10.20546/ijcmas.2017.611.475 (2017).

30. Hemida, K. A. \& Reyad, A. M. M. Improvement salt tolerance of safflower plants by endophytic bacteria. Hortic. Plant Res.5, 38-56. https://doi.org/10.18052/www.scipress.com/JHPR.5.38 (2019).

31. Soussi, A. et al. Plant-associated microbiomes in arid lands: diversity, ecology and biotechnological potential. Plant Soil405, 357370. https://org/10.1007/s11104-015-2650-y (2016).

32. Szymańska, S. et al. Bacterial microbiome of root-associated endophytes of Salicornia europaea in correspondence to different levels of salinity. Sci. Pollut. Res. 25, 25420-25431. https://doi.org/10.1007/s11356-018-2530-0 (2018).

33. Liu, Y., Lai, Q., Du, J. \& Shao, Z. Bacillus zhangzhouensis nov. and Bacillus australimaris sp. nov. Int. J. Syst. Evol. Microbiol. 66(3), 1193-1199. https://doi.org/10.1099/ijsem.0.000856 (2016).

34. Satomi, M., La Duc, M. T. \& Venkateswaran, K. Bacillus safensis nov., isolated from spacecraft and assembly-facility surfaces. Int. J. Syst. Evol. Microbiol.56(8), 1735-1740. https://doi.org/10.1099/ijs.0.64189-0 (2006).

35. Hao, K. et al. Effectiveness of Bacillus pumilus PDSLzg-1, an innovative Hydrocarbon-Degrading Bacterium conferring antifungal and plant growth-promoting function. 3 Biotech9(8), 305. https://org/10.1007/s13205-019-1842-1 (2019).

36. Yoon, S. H. et al. Introducing EzBioCloud: A taxonomically united database of $16 \mathrm{~S}$ rRNA and whole genome assemblies. J. Syst. Evol. Microbiol.67(5), 1613-1617. https://doi.org/10.1099/ijsem.0.001755 (2017).

37. Rao, Q. et al. Pseudomonas ovata nov., isolated from the skin of the tail of farmed Murray cod (Maccullochella peelii peelii) with a profound ulceration. Curr. Microbiol. 76(10), 1168-1174. https://doi.org/10.1007/s00284-019-01729-1(2019).

38. Humbert, M. V. \& Christodoulides, M. Atypical, yet not infrequent, infections with NeisseriaPathogens 9(1),10. https://doi.org/10.3390/pathogens9010010 (2020).

39. Watts, J., De Villiers, O. \& Watts, L. Sterilization of wheat seeds for tissue culture purposes. Afr. J. Bot.59(6), 641-642. https://doi.org/10.1016/s0254-6299(16)30683-4 (1993).

40. Metwaly, A., Salama G. M., \& Ali. G. A. Using hydrogen peroxide for reducing bacterial contamination in date palm tissue culture. J. Adv. Agric. Sci. Technol. 5(4), 25-33. (2018).

41. Alsharif, W., Saad, M.M. \& Hirt, H. Desert microbes for boosting sustainable agriculture in extreme environments. Microbiol.11, 1666. https://doi.org/10.3389/fmicb.2020.01666 (2020).

42. Basu, S. et al. Evolution of bacterial and fungal growth media. Bioinformation11(4), 182-184 https://org/10.6026/97320630011182 (2015).

43. Aanniz, T. et al. Thermophilic bacteria in Moroccan hot springs, salt marshes and desert soils. J. Microbiol.46(2), 443-453. https://doi.org/10.1590/S1517-838246220140219 (2015).

44. Truyens, S., Weyens, N., Cuypers, A. \& Vangronsveld, J. Bacterial seed endophytes: genera, vertical transmission and interaction with plants. Microbiol. Rep.7(1), 40-50. https://doi.org/10.1111/1758-2229.12181(2015). 
45. López, S. M. Y. et al. Microbial endophytes that live within the seeds of two tomato hybrids cultivated in Argentina. Agronomy8(8), 136. https://org/10.3390/agronomy8080136 (2018).

46. Panosyan, H., Hakobyan, A., Birkeland, N. K. \& Trchounian, A. Bacilli community of saline-alkaline soils from the Ararat Plain (Armenia) assessed by molecular and culture-based methods. Appl. Microbiol.41(3), 232-240. https://doi.org/10.1016/j.syapm.2017.12.002 (2018).

47. Panosyan, $\mathrm{H}$. Thermophilic Bacilli isolated from armenian geothermal springs and their potential for production of hydrolytic enzymes. J. Biotechnol. Bioeng. 3(7), 248-253. https://doi.org/10.25141/2475-3432-2017-7.0239 (2017).

48. Werma, J. P. et al. Characterization and screening of thermophilic Bacillus strains for developing plant growth promoting consortium from hot spring of Leh and Ladakh region of India. Microbiol.9, 1293. https://doi.org/10.3389/fmicb.2018.01293 (2018).

49. El-Deeb, B., Bazaid, S., Gherbawy, Y. \& Elhariry, H. Characterization of endophytic bacteria associated with rose plant (Rosa damascena trigintipeta) during flowering stage and their plant growth promoting traits. Plant Interact. 7(3), 248-253. https://doi.org/10.1080/17429145.2011.637161(2012).

50. Ayob, F. W. \& Simarani, K. Endophytic filamentous fungi from a Catharanthus roseus: Identification and its hydrolytic enzymes. Saudi Pharm. J.24(3), 273-278. https://org/10.1016/j.jsps.2016.04.019 (2016).

51. Duarah, I., Deka, M., Saikia, N. \& Deka Boruah, H. P. Phosphate solubilizers enhance NPK fertilizer use efficiency in rice and legume cultivation. 3(1), 227-238. https://doi.org/10.1007/s13205-011-0028-2 (2011).

52. Kaneko, M., Itoh, H., Ueguchi-tanaka, M., Ashikari, M. \& Matsuoka, M. The alpha-amylase induction in endosperm during rice seed germination is caused by gibberellin synthesized in epithelium. Plant Physiol.128(4), 1264-1270. https://doi.org/10.1104/pp.010785.1264. (2002).

53. Appleford, N. E. J. \& Lenton, J. R. Hormonal regulation of a-amylase gene expression in germinating wheat (Triticum aestivum) grains. Physiol Plant. 100(3), 534-542. https://doi.org/10.1111/j.1399-3054.1997.tb03058.x (1997).

54. Yamaguchi, S. Gibberellin metabolism and its regulation. Rev. Plant Biol.59, 225-251. https://doi.org/10.1146/annurev.arplant.59.032607.092804 (2008).

55. Reimer, L.C. et al. BacDive in 2019: bacterial phenotypic data for High-throughput biodiversity analysis. Nucleic Acids Res. 47(D1), D631-D636. https://org/10.1093/nar/gky879 (2019).

56. Sirko, A. \& Brodzik, R. Plant ureases: roles and regulation. Acta Biochim. Pol.47(4),1189-1195. (2000).

57. Bibi, S., Oualha, M., Ashfaq, M., Suleiman, M. \& Zouari, N. Isolation, differentiation and biodiversity of ureolytic bacteria of Qatari soil and their potential in microbially induced calcite precipitation (MICP) for soil stabilization. RSC Adv.8, 5854-5863. https://doi.org/10.1039/C7RA12758H (2018).

58. Eevers, N., Gielen, M., Sánchez-López, A., Jaspers, S., White, J. C., Vangronsveld, J., et al. Optimization of isolation and cultivation of bacterial endophytes through addition of plant extract to nutrient media. Biotechnol.8(4), 707-715. https://doi.org/10.1111/1751-7915.12291 (2015).

59. Oren, A. Microbial life at high salt concentrations: phylogenetic and metabolic diversity. Biosyst.4, 2. https://doi.org/10.1186/17461448-4-2 (2008).

60. Chimwamurombe, P. M., Grönemeyer, J. L. \& Reinhold-Hurek, B. Isolation and characterization of culturable seed-associated bacterial endophytes from gnotobiotically grown Marama bean seedlings. FEMS Microbiol. Ecol.92(6), 083. https://org/10.1093/femsec/fiw083 (2016).

61. Herrera Díaz, S., Grossi, C., Zawoznik, M., and Groppa, M. D. Wheat seeds harbour bacterial endophytes with potential as plant growth promoters and biocontrol agents of Fusarium graminearum. Res.186-187, 37-43. https://doi.org/10.1016/j.micres.2016.03.002 (2016).

62. Wassermann, B., Cernava, T., Müller, H., Berg, C. \& Berg, G. Seeds of native alpine plants host unique microbial communities embedded in cross-kingdom networks. Microbiome7(1), 108. https://org/10.1186/s40168-019-0723-5 (2019).

63. Dai, Y. et al. The differences and overlaps in the seed-resident microbiome of four Leguminous and three GramineousMicrob. Biotechnol.13(5), 1461-1476. https://doi.org/10.1111/1751-7915.13618 (2020).

64. DeBruyn, J. M., Nixon, L. T., Fawaz, M. N., Johnson, A. M. \& Radosevich, M. Global biogeography and quantitative seasonal dynamics of Gemmatimonadetes in soil. Environ. Microbiol.77(17), 6295-6300. https://doi.org/10.1128/AEM.05005-11 (2011). 
65. Dharamshi, J. E. et al. Marine sediments illuminate chlamydiae diversity and evolution. Biol.30(6), 1032-1048. https://doi.org/10.1016/j.cub.2020.02.016 (2020).

66. Speirs, L., Rice, D., Petrovski, S. \& Seviour, R. J. The phylogeny, biodiversity, and ecology of the Chloroflexi in activated sludge. Microbiol.10, 2015. https://doi.org/10.3389/fmicb.2019.02015 (2019).

67. Griffiths, E. \& Gupta, R. S. Identification of signature proteins that are distinctive of the Deinococcus-Thermus phylum. Microbiol.10(3), 201-208. (2007).

68. Guo, J., Bowatte, S. \& Hou, F. Diversity of endophytic bacteria and fungi in seeds of Elymus nutans growing in four locations of Qinghai Tibet Plateau, China. Plant Soil459(3), 49-63. https://org/10.1007/s11104-020-04608-y (2021).

69. Dojka, M. A., Harris, J. K. \& Pace, N. R. Expanding the known diversity and environmental distribution of an uncultured phylogenetic division of bacteria. Environ. Microbiol.66(4), 1617-1621. https://doi.org/10.1128/aem.66.4.1617-1621.2000 (2000).

70. Forni, C., Duca, D. \& Glick, B. R. Mechanisms of plant response to salt and drought stress and their alteration by rhizobacteria. Plant Soil410, 335-356. https://org/10.1007/s11104-016-3007-x (2017).

71. Eida, A. A. et al. Desert plant bacteria reveal host influence and beneficial plant growth properties. PloS One13(12), e0208223. https://org/10.1371/journal.pone.0208223 (2018).

72. Marasco, R. et al. Rhizosheath microbial community assembly of sympatric desert speargrasses is independent of the plant host. Microbiome6(1), 215. https://org/10.1186/s40168-018-0597-y (2018).

73. Huang, X. L. et al. Isolation and bioactivity of endophytic filamentous actinobacteria from tropical medicinal plants. J. Biotechnol. 11(41), 9855-9864. https://doi.org/10.5897/AJB11.3839 (2012).

74. Sánchez-Porro, C. et al. Description of Kushneria aurantia nov., sp. nov., a novel member of the family Halomonadaceae, and a proposal for reclassification of Halomonas marisflavi as Kushneria marisflavi comb. nov., of Halomonas indalinina as Kushneria indalinina comb. nov. and of Halomonas avicenniae as Kushneria avicenniae comb. nov. Int. J. Syst. Evol. Microbiol. 59(2), 397405. https://doi.org/10.1099/ijs.0.001461-0 (2009).

75. Fu, X. et al. Bacillus pumilusgroup comparative genomics: toward pangenome features, diversity, and marine environmental adaptation. Microbiol.12(571212). https://doi.org/10.3389/fmicb.2021.571212 (2021).

76. Mitter, B. et al. (2017). A new approach to modify plant microbiomes and traits by introducing beneficial bacteria at flowering into progeny seeds. Microbiol.8(11). https://doi.org/10.3389/fmicb.2017.00011

77. Okunishi, S., Sako, K., Mano, H., Imamura, A. \& Morisaki, H. Bacterial flora of endophytes in the maturing seed of cultivated rice (Oryza sativa). Microbes Environ.20(3), 168-177. https://org/10.1264/jsme2.20.168 (2005).

78. Hua, M. D. S. et al. Metabolomic compounds identified in Piriformospora indica-colonized Chinese cabbage roots delineate symbiotic functions of the interaction. Rep.7(1),9291. https://doi.org/10.1038/s41598-017-08715-2 (2017).

79. Walitang, D. I. et al. The influence of host genotype and salt stress on the seed endophytic community of salt-sensitive and salttolerant rice cultivars. BMC Plant Biol.18, 51. https://org/10.1186/s12870-018-1261-1 (2018).

80. Piwowarczyk, R. et al. First report of the holoparasitic flowering plant Cistanche armena on Caspian Manna (Alhagi maurorum) in Armenia. Plant Dis. 101(3), 512. https://org/10.1094/PDIS-10-16-1469-PDN (2017).

81. Piwowarczyk, R. et.al Holoparasitic Orobanchaceae (Cistanche, Diphelypaea, Orobanche, Phelipanche) in Armenia: distribution, habitats, host range and taxonomic problems. Phytotaxa386(1), 001-106. https://org/10.11646/phytotaxa.386.1.1 (2019).

82. Sánchez-Pedraja, Ó. et al. [continuously updated] Index of Orobanchaceae. Grupo botánico cantábrico (GBC), Liérganes Cantabria Spain, http://www.farmalierganes.com/Otrospdf/publica/Orobanchaceae\%20Index.htm. [Accessed 29 March 2021]. (2016).

83. Barthlott, W. Epidermal and seed surface characters of plants: systematic applicability and some evolutionary aspects. J. Bot.1(3), 345-355. https://doi.org/10.1111/j.1756-1051.1981.tb00704.x (1981).

84. Hassan, M., Osman, A., Rugheim, A., Ali A., Abdelgani, M. \& Babiker, A. (2015). Effects of bacterial isolates and strains on Phelipanche ramosa (L.) Pomel haustorium initiation. J. Biosci.6(2), 296-303. https://doi.org/10.12692/ijb/6.2.296-303

85. Pankova, Ye., Redly, M., Aidarov, I. \& Pestov, L. Amelioration of alkali(soda-saline) soils. Agricultural Land Improvement: Amelioration and Reclamation2, 267-288. (2009).

86. Saitou, N. \& Nei, M. The neighbor-joining method: a new method for reconstructing phylogenetic trees. Biol. Evol. 4(4), $406-425$. https://doi.org/10.1093/oxfordjournals.molbev.a040454 (1987).

87. Kumar, S., Stecher, G., Li, M., Knyaz, C. \& Tamura, K. MEGA X: molecular evolutionary genetics analysis across computing platforms. Biol. Evol.35(6), 1547-1549. https://doi.org/10.1093/molbev/msy096 (2018).

Page 20/25 
88. Klindworth, A. et al. Evaluation of general 16S ribosomal RNA gene PCR primers for classical and next-generation sequencingbased diversity studies. Nucleic Acids. Res.41(1), e1. https://org/10.1093/nar/gks808 (2013).

89. Tille, P.M. \& Forbes, B. A. Bailey \& Scott's diagnostic microbiology (Thirteenth edition.). (St. Louis, Missouri: Elsevier, 2014).

90. Reiner, K. Catalase Test Protocol. (ASM Washington DC, 2010).

91. Brink, B. Urease Test Protocol. (American Society for Microbiology, 2016).

92. Gupta, R., Kale, P., Rathi, M. \& Jadhav, N. Isolation, characterization and identification of endophytic bacteria by $16 \mathrm{~S}$ rRNA partial sequencing technique from roots and leaves of Prosopis cinerariaAsian J. Plant Sci. Res.5(6), 36-43 (2015).

93. Smibert, R. \& Krieg, N. "Phenotypic characterization", in Methods for general and Molecular Bacteriology, (eds. Gerhardt, P., Murray, R.G.E., Wood, W.A., Krieg, N.R. 607-654, (ASM, Washington, DC, 1994).

94. Jacobs, M. B. \& Gerstein, M. J. Handbook of microbiology, (Princeton NJ: Van Nostrand, 1960).

95. Dinesh, R. et al. Isolation, characterization, and evaluation of multi-trait plant growth promoting rhizobacteria for their growth promoting and disease suppressing effects on ginger. Res.173, 34-43. https://doi.org/10.1016/j.micres.2015.01.014 (2015).

96. Gusmiaty Restu, M., Bachtiar, B. \& Larekeng, S.H. Gibberellin \& IAA production by Rhizobacteria from various private forest. IOP Conf. Ser.: Earth Environ. Sci.270, 012018 (2019).

97. Nautiyal, C. S. An efficient microbiological growth medium for screening phosphate solubilizing microorganisms. FEMS Lett.170(1), 265-270 (1999).

\section{Figures}

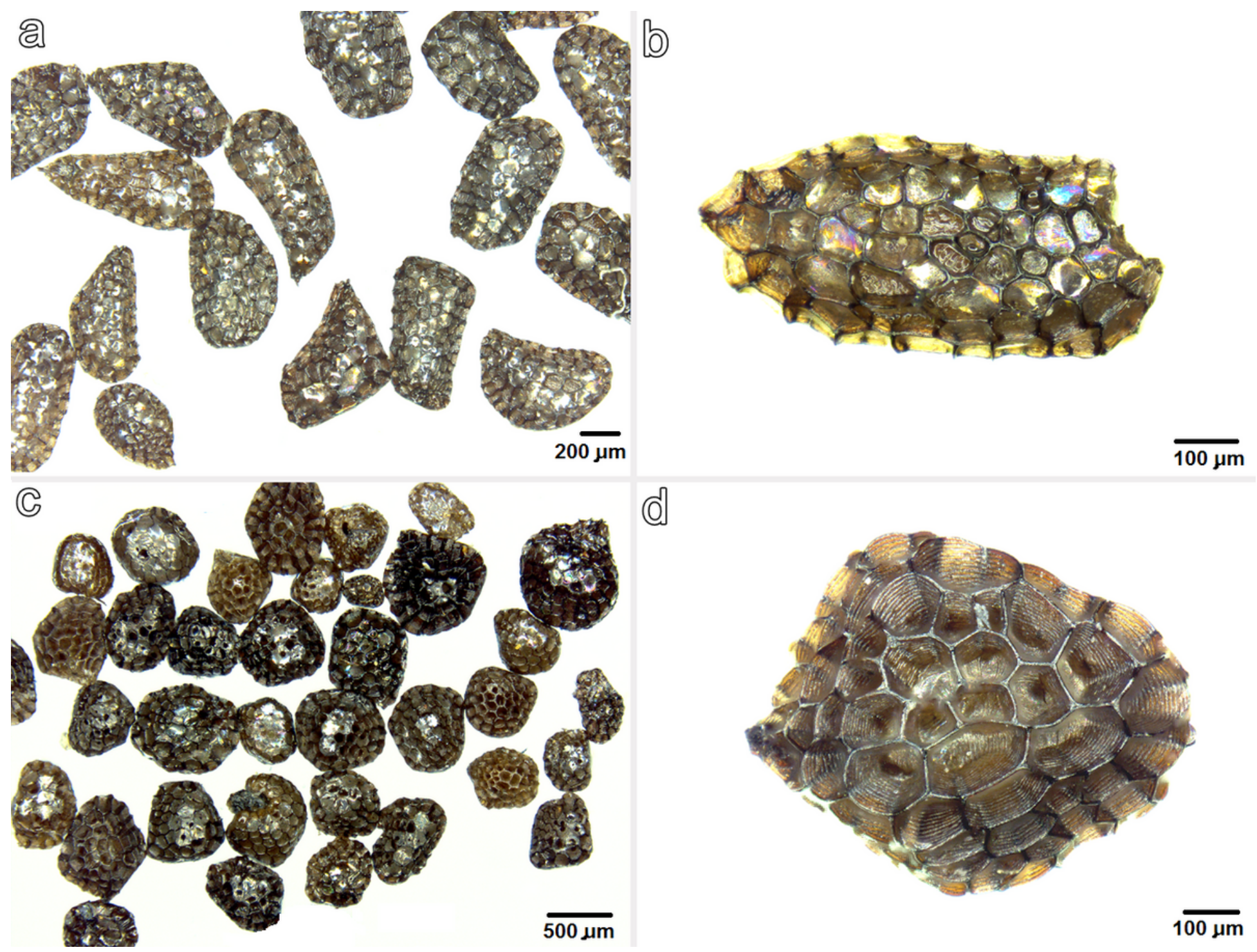




\section{Figure 1}

ZOOM microscopy micrographs of seeds: (a, b) Cistanche armena, (c, d) C. phelypaea.

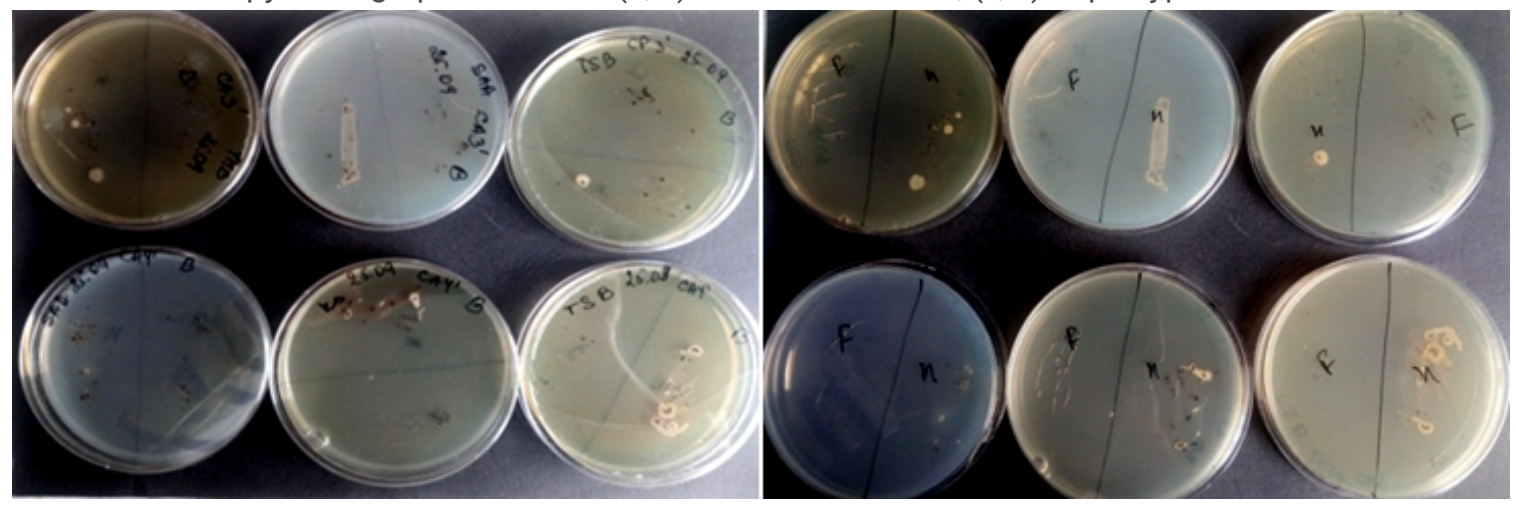

\section{Figure 2}

Samples of seeds (Cistanche armena and C. phelypaea) planted intact $(F)$ and after mechanical homogenization $(H)$ on different growth media after surface sterilization. On the left side of the Petri dishes the intact ( $F$ ) seeds (no bacterial growth) and on the right side crushed $(\mathrm{H})$ seeds (growth of bacterial endophytes).

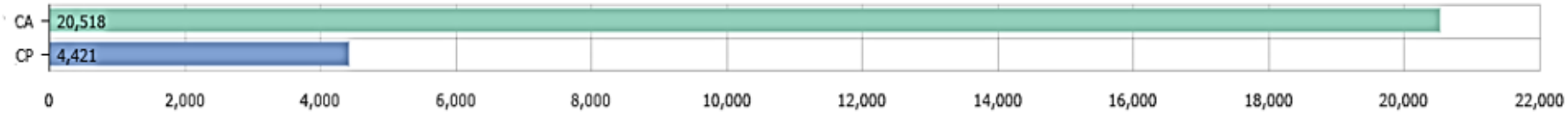

a) Number of readings after filtering

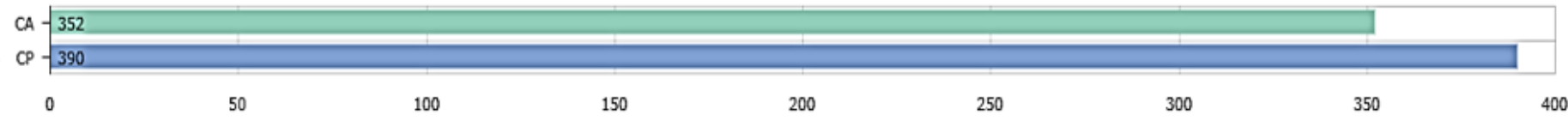

b) Number of identified OTUs in the tested samples

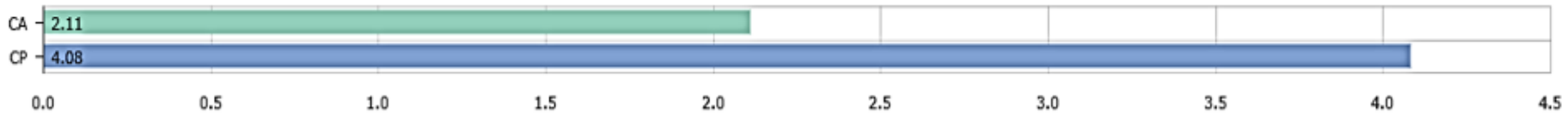

c) Shannon-Wiener biodiversity index values for the studied samples

\section{Figure 3}

The values of readings of seed-endophytes of Cistanche armena (CA) and C. phelypaea (CP), after filtering (a), identified OTUs (b), Shannon-Wiener biodiversity index (c) 


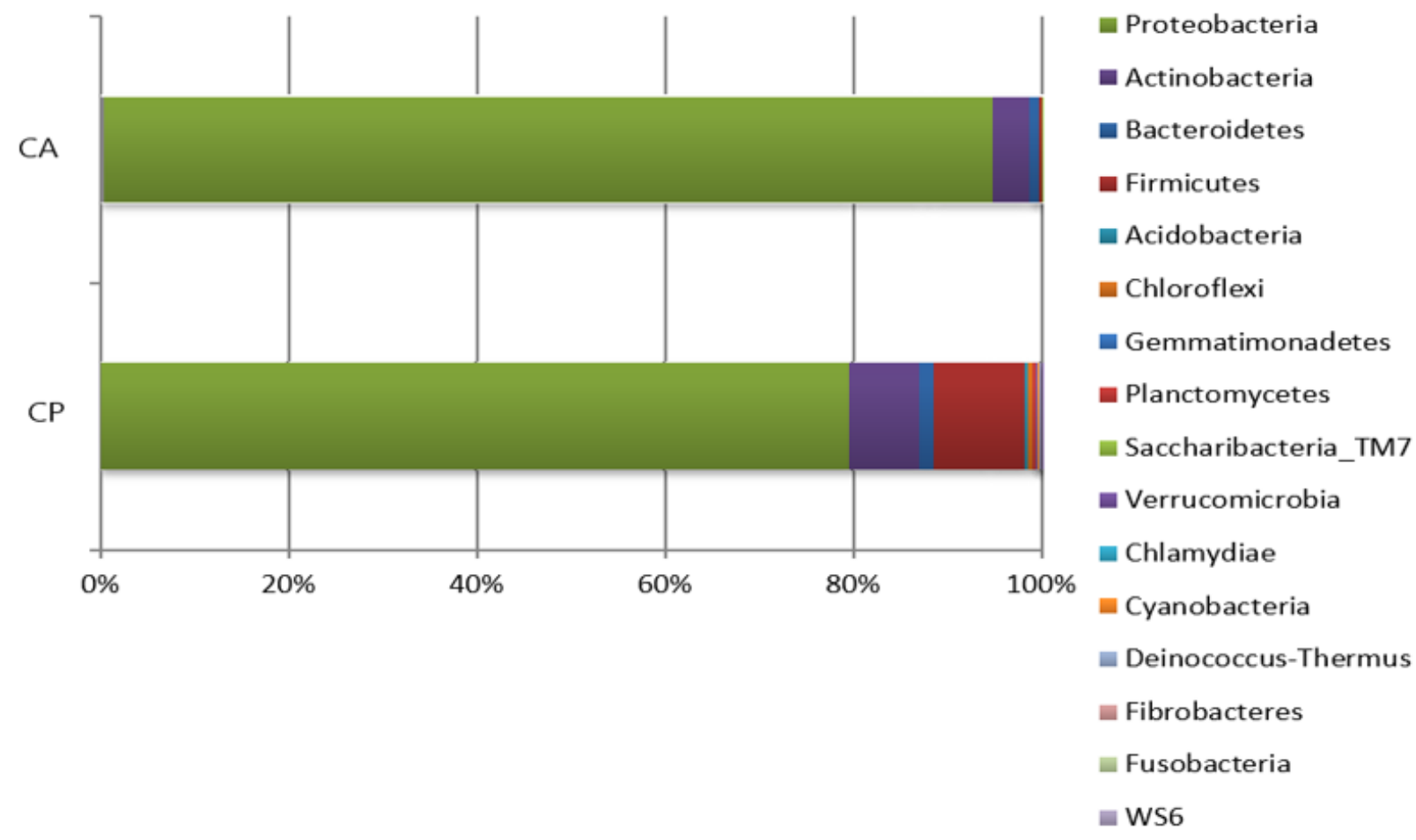

\section{Figure 4}

Composition of the total seed endophytic communities of holoparasitic plant species Cistanche at phylum level.

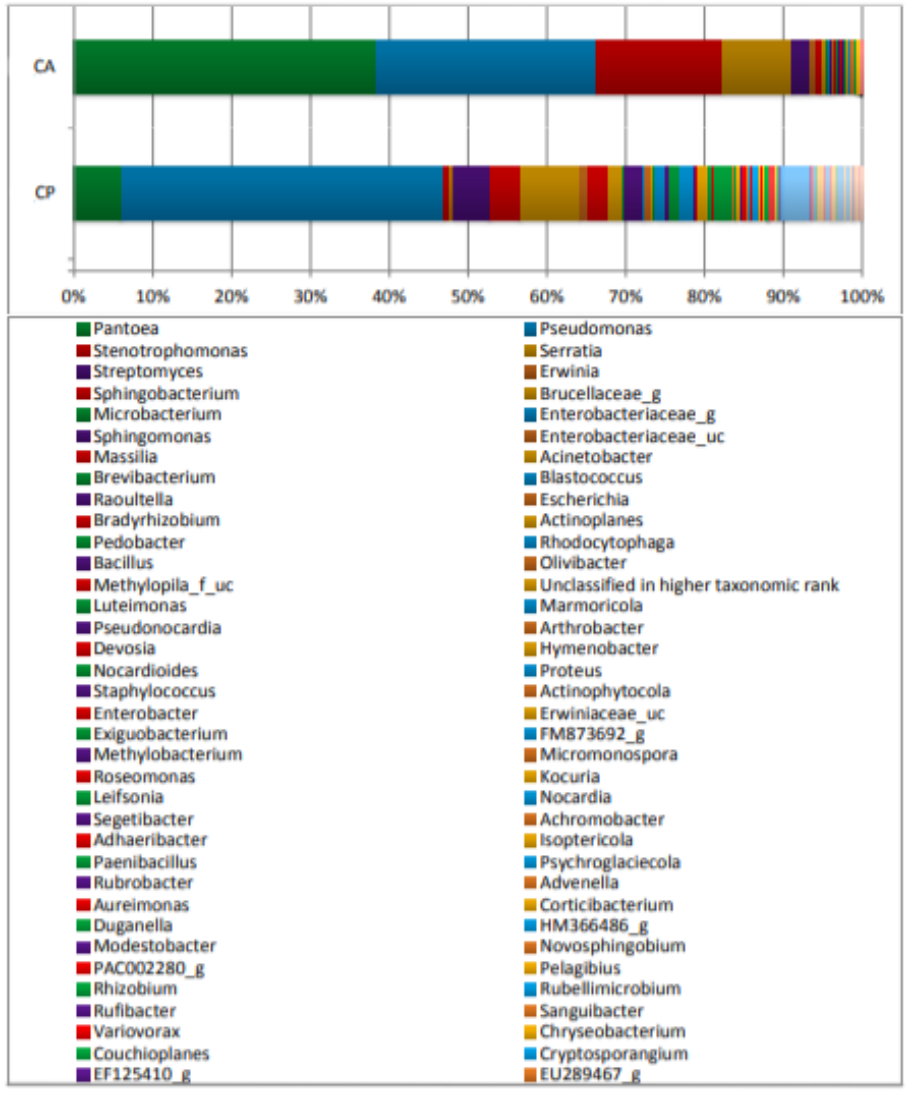

\section{Figure 5}

Composition of the total seed endophytic communities of holoparasitic plant species Cistanche at genus level. 

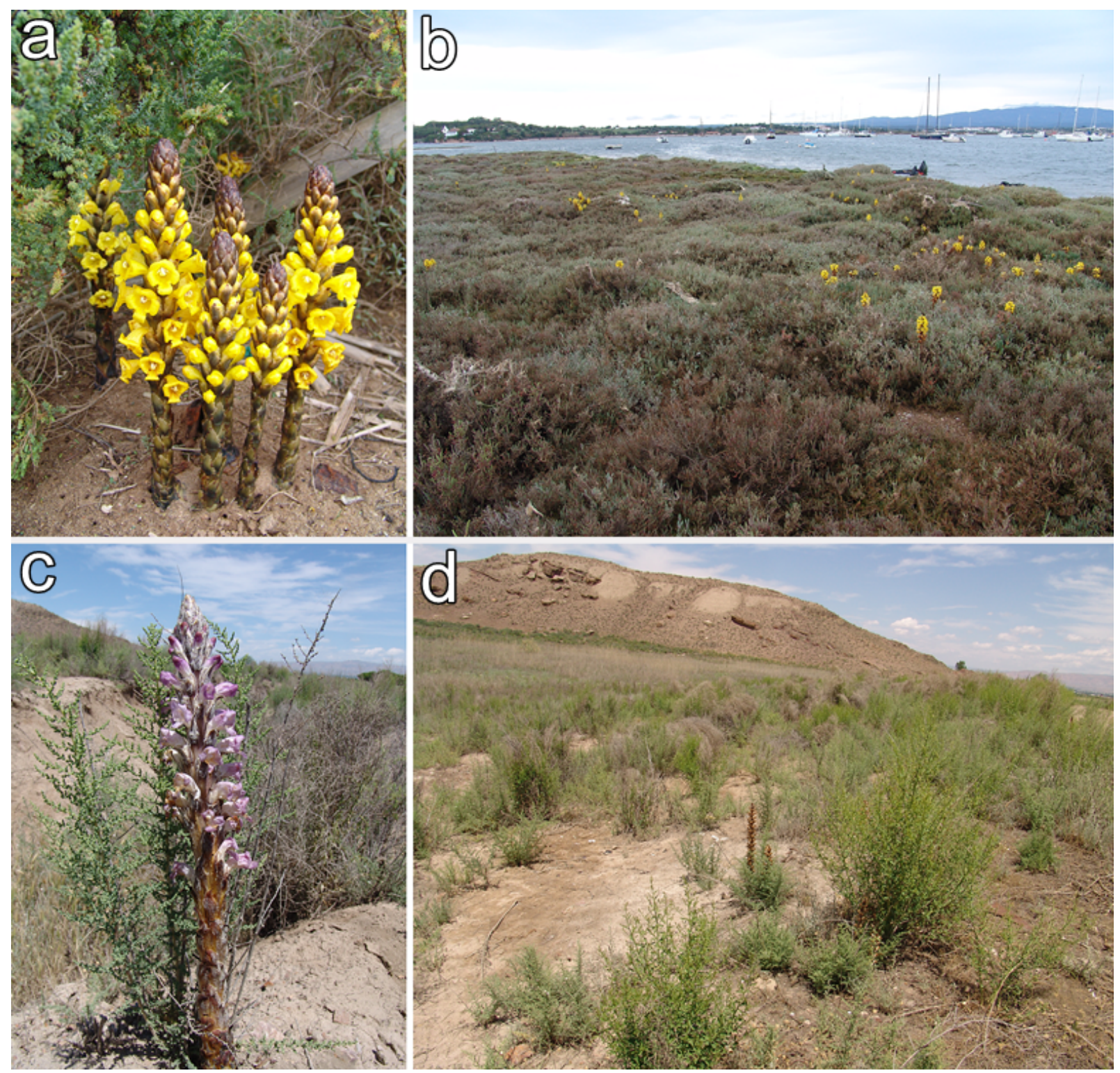

\section{Figure 6}

General habit of the studied species and their habitats: $(a, b)$ Cistanche phelypaea in the coastal salt marshes in Portugal, $(c, d) C$. armena in the halophytic vegetation of semi-desert in Armenia. Phot. R. Piwowarczyk 


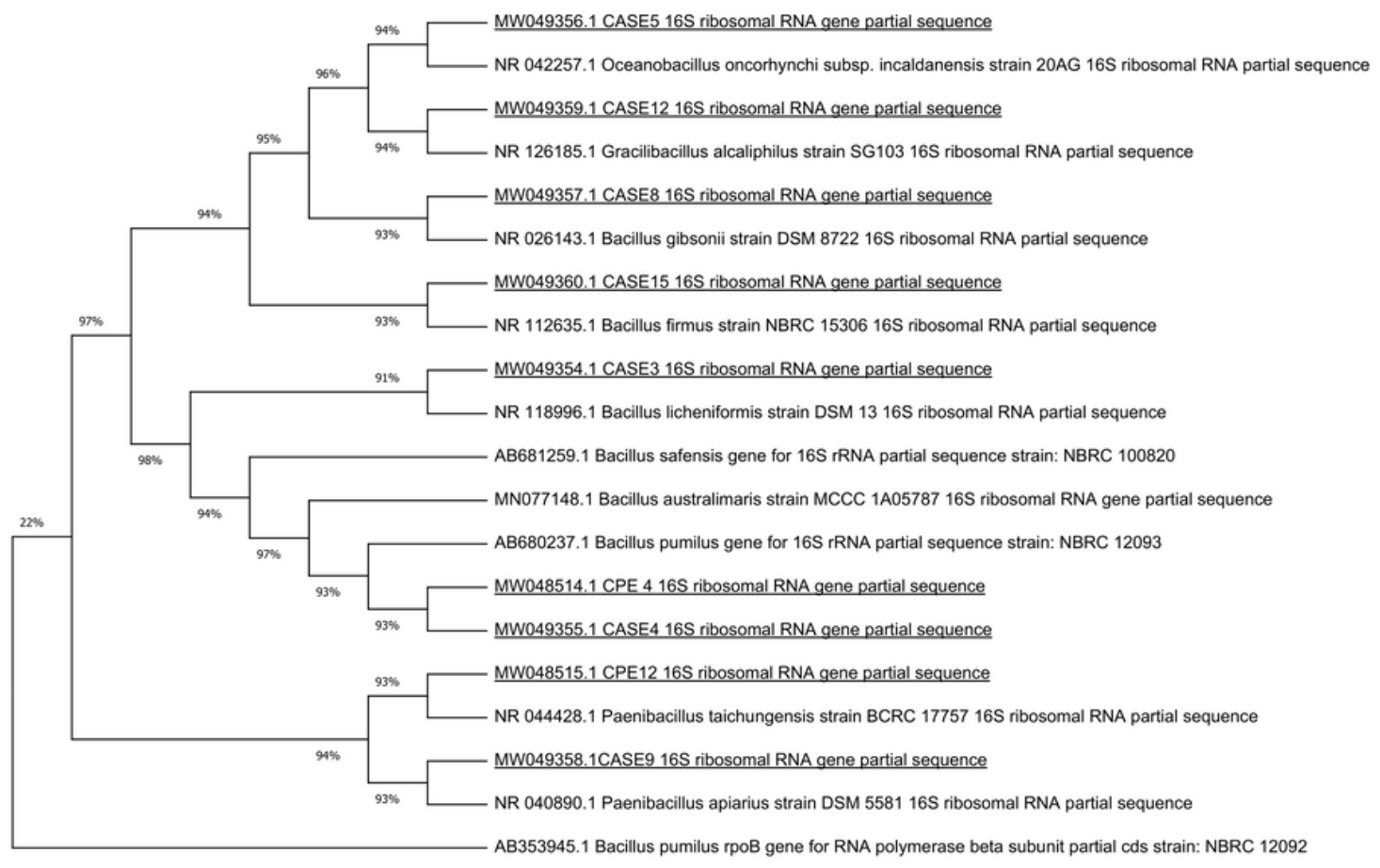

\section{Figure 7}

Phylogenetic tree of bacterial endophytes isolated from Cistanche armena and C. phelypaea seeds.

\section{Supplementary Files}

This is a list of supplementary files associated with this preprint. Click to download.

- Petrosyanetal.SupplementaryInformation.docx

- Petrosyanetal.SupplementaryMaterial1.xlsx 